Maria Khachaturyan*

\title{
A typological portrait of Mano, Southern Mande
}

https://doi.org/10.1515/lingty-2020-2050

\begin{abstract}
This paper provides a typological survey of Mano, a Mande language of Guinea and Liberia. It sketches a linguistic portrait of Mano as a representative member of the Southern branch of the Mande family. The family features shared by Mano include S-Aux-O-V-X word order, the parallelism between nominal and verbal syntax, and the ubiquity of passive lability. The branch features include rich tonal morphology, the unstable character of nasal consonants, and rich pronominal paradigms, including auxiliaries that index the person and number of the subject. Some of the features presented here have not been sufficiently analyzed in the Mandeist literature, so it is unclear how unusual Mano is in comparison to other Mande languages in terms of the large class of inalienably possessed nouns, or the clause-level nominalization that may include another clause as its constituent. Finally, some properties are almost certainly specific to Mano, such as the dedicated tonal forms used in conditional clauses. This paper puts Mano in its typological context, elaborating on those features which are cross linguistically well attested versus those which are cross linguistically rare.
\end{abstract}

Keywords: Mande, Mano, tone, grammatical tone, possessive split, subordination, inclusory pronouns, lability, information structure

\section{Introduction}

Mano (Ethnologue language name: Maan, ISO code: mev, glottolog code: mann1248) has 390,000 speakers in Guinea and Liberia and is one of the several dozen languages spoken in these countries. Belonging to Mande, a major family of languages spoken throughout West Africa, Mano shares many of its distinctive typological features but

\footnotetext{
*Corresponding author: Maria Khachaturyan [mar'ija (m'aša) xačaturj'an], University of Helsinki, P.O Box 24 (Unioninkatu 40), Helsingin Yliopisto, 00014, Helsinki, Finland, E-mail: maria.khachaturyan@helsinki.fi. https://orcid.org/0000-0001-6758-9575
} 
also exhibits several peculiar characteristics of its own. This paper provides an outline of the most original linguistic features of the language both from a Mande perspective and in the context of broader cross-linguistic comparison. Although an exhaustive typological analysis is beyond the scope of this paper, the Mano data is presented against a minimal set of relevant typological and/or areal overviews, as well as the descriptive and comparative literature on Mande languages.

The work on Mano presented in this analysis is based on fifteen months of fieldwork conducted by the author between 2009 and 2019. The core of the fieldwork materials is a multi-genre collection of spontaneous texts in Mano which includes narratives, as well as conversations and ritual speech, Christian and traditional. Many examples are drawn from the spoken corpus, but some were elicited, especially those illustrating morphological contrasts, and all examples are marked correspondingly (nat. and el.). A grammar can be found in Khachaturyan (2015), and some typological findings were shown in Khachaturyan (2014). ${ }^{1}$

Mano belongs to the Southern branch of the Mande language family, whose status within the Niger-Congo phylum is debated. Thus, while Greenberg's original classification of African languages included Mande languages, the point of view which is still supported by some scholars, such as Vydrin (2016), Dimmendaal and Storch (2016) argue that Mande languages do not belong to Niger-Congo, as they do not share with it one of its most outstanding typological features - noun classes (an attempt to reconstruct noun classes in Mande was done by Vydrin 2006). The Mande languages are divided into Eastern and Western branches. The Eastern Mande languages include Southern Mande (Mano, but also Dan, Tura, Beng, Guro, Mwan, and Wan will be mentioned throughout the paper). Western Mande languages include Northwestern Mande, such as Soninke, as well as Central Mande and, in particular, the Manding group. This latter group includes the BamanaManinka-Jula dialect continuum, the most spoken and the best described Mande varieties, as well as Mandinka, Kassonke, and some others. The Western branch also includes the Southwestern Mande group and in particular, the Kpelle language, with which Mano is in contact and shares many of its structural features. For an overview of the family, see Vydrin et al. (2017) and Vydrin (2018).

The analysis begins with an overview of the sociolinguistic situation, including the patterns of multilingualism and issues of language contact (Section 2). It then proceeds with a sketch of Mano phonology with its typologically original features. These include the existence of labial-velar consonants, a syllabic nasal and the unstable phonologization status of nasal consonants (Section 3.1), as well as some

1 The present article goes beyond these works by incorporating material on Mano collected in subsequent years and offers a more detailed typological background by consulting recent publications in Mande, broader African linguistics and typological literature. 
issues in phonotactics, such as distributional asymmetries within stems and the exceptional status of labialized and non-labialized velar consonants with respect to vowel harmony (Section 3.2). Section 4 is dedicated to the morphosyntax of NPs, with its several cross-linguistically outstanding features: rich pronominal paradigms (Section 4.1), the existence of a dedicated series of inclusory pronouns (Section 4.2), the expression of number (Section 4.3) and the possessive split (Section 4.4). Section 5 presents a selection of features in the verbal syntax: SOVX word order (Section 5.1), nominalization (Section 5.2), the status of postverbal arguments (Section 5.3) as well as transitivity and lability (Section 5.4). Section 6 introduces some interesting features of the tense, aspect, mood and polarity (TAMP) system, including a rich verbal morphology, especially tonal, with TAMP values (Section 6.1), a rich auxiliary system (Section 6.2), asymmetric negation (Section 6.3) and the polysemy of the prospective auxiliary (Section 6.4). Finally, Section 7 presents some issues on clause combining such as the syntax of the conjoint form (Section 7.1) as well as the morphology and semantics of conditional clauses (Section 7.2). Section 8 concludes.

\section{Sociolinguistic situation}

The Mano (or máámìa) populate a mountainous area in South-Eastern Guinea and Northern Liberia. Guinean Mano has approximately 85000 speakers and is one of the 34 indigenous languages spoken in Guinea. In Liberia, Mano is spoken by about 305000 people. Out of the 27 indigenous languages in Liberia, Mano is the fifth most spoken language.

Native speakers in Guinea distinguish between three Mano dialects which correspond to clan names: Zaan (zàà)), the easternmost dialect spoken around the town of Bossou, Maa (màá), the central dialect spoken in the city of Nzérékoré and to the south of it, and Kpeinson (kpéńsう̃), the Western dialect spoken around the town of Diécké. Liberia also has three dialects that speakers distinguish: the Northern dialect Maalaa (máá lāā), which is spoken around Sanniquellie; the Central dialect Maazein (máá zèń), spoken in Ganta; and the Southern dialect Maabei (máá bèí), which is spoken in Saklepea. It is likely that several other varieties are spoken to the south of Saklepea. While conducting a dialect survey of Liberian varieties (Khachaturyan 2018), I traveled with a speaker of the central Guinean dialect, Maa. This speaker did not encounter problems in understanding Liberian Mano, with the obvious exception of borrowings from English, a language he did not speak. The basic lexicon of Liberian Mano (at least within the limits of the 100-word Swadesh list) is predominantly the same in all Mano dialects that I have data on. Due to the few lexical differences between dialects, it is not possible to postulate sharp dialectal boundaries, but rather 
place different varieties on a North to South continuum beginning with Zaan, Maa and, presumably, Maalaa, followed by Kpeinson and Maazein. In contrast, the southernmost Liberian dialect, Maabei, has a highly distinctive phonology and in part lexicon which distinguishes it from other Mano varieties.

Most Mano speak, at least to some extent, either French (Guinea) or English (Liberia). Many of the Mano in Guinea are fluent in the local majority languages, such

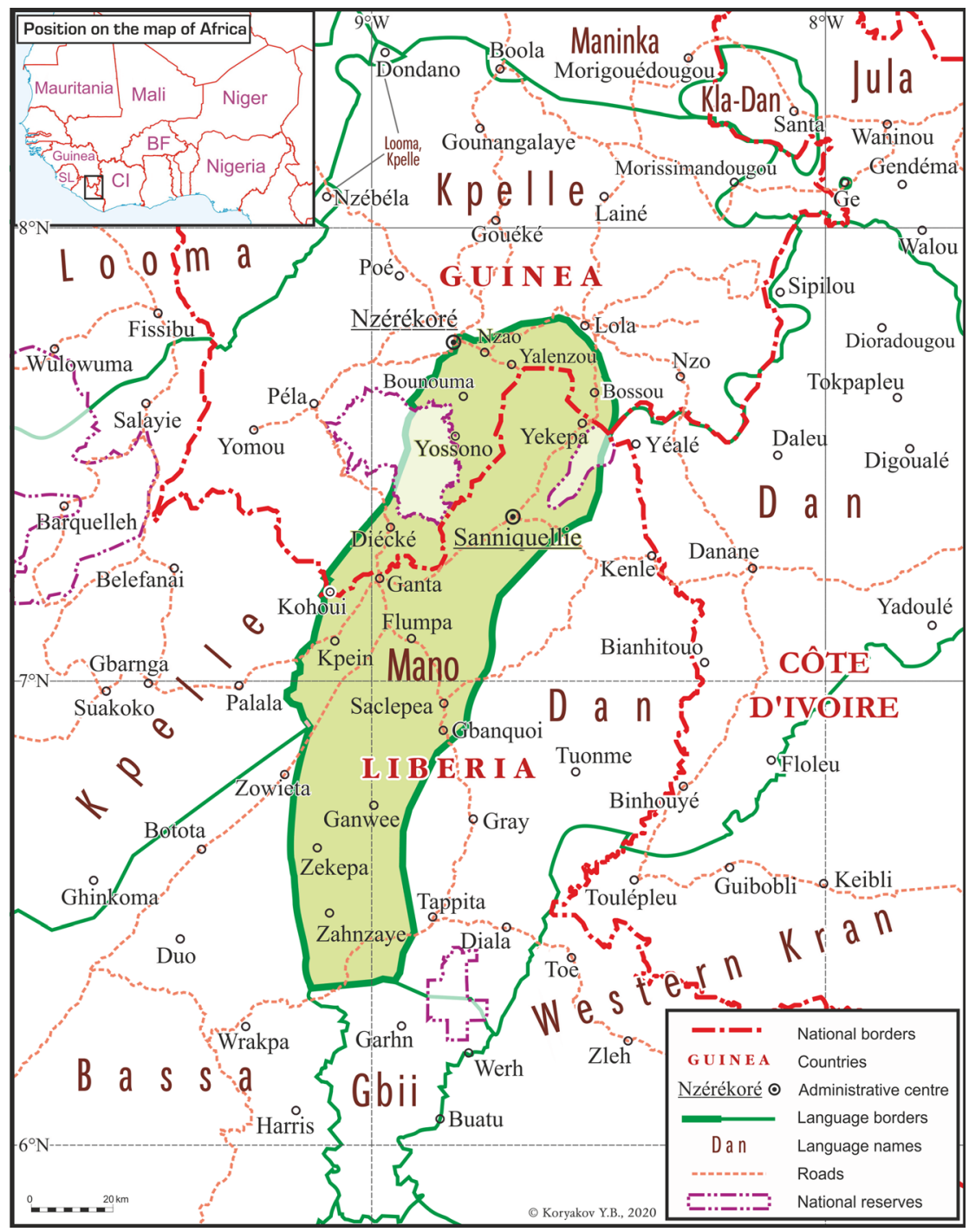

Figure 1: Mano and the main contact languages: Kpelle, Dan, Manding, adapted from Vydrine et al. (2000). 
as Kpelle and Maninka, while in Liberia, particularly in the South of the Mano zone, many Mano speak Dan. The dialect variation may be partially due to the influence of Kpelle on Guinean varieties and Dan on Liberian varieties (see Figure 1 for a language map). Evidence suggests that the contact with Kpelle has shaped several aspects of the phonology and grammar of Guinean Mano. These influences include agreement patterns (Konoshenko 2015), as well as the phonologization of nasal consonants and patterns of vowel assimilation in suffixes (Khachaturyan 2018). Guinean Mano has multiple borrowings, especially in the cultural lexicon, from Kpelle. Many of these borrowings are originally Manding (Khachaturyan 2020).

The only written source in Mano in large circulation is the translation of the New Testament published in Liberia (UBS 1978). There have been several independent initiatives to promote literacy, with the main actors including a protestant missionary in Guinea, Samantha Mero, who worked on the translation of the Old Testament. In addition to her translation work, Mero produced literacy materials and organized literacy workshops. In Liberia, the Liberian Translation and Literacy Organization (LIBTRALO) has, among its affiliated members, Leelamen Zarwolo, an active Mano speaker who produces literature in Mano and works to promote literacy. However, Mano has never been the language of education in either of the countries. There is regular radio broadcasting in Mano in Nzérékoré and several Mano radio stations broadcast in Liberia.

\section{Phonetics and phonology}

\subsection{Phoneme inventory}

The consonant and vowel inventories of Mano are provided in Tables 1 and 2, respectively. Three features of the phonemic inventories deserve special attention: labial-velar consonants, the syllabic nasal and nasal consonants.

Labial-velar consonants are identified by Güldemann (2008a: 156-158) as a typical feature for languages of the North-Western area of sub-Saharan Africa (which is also referred to as the Macro-Sudan Belt) and are common to Mande languages but extremely rare outside Africa. Mano has two of these consonants:

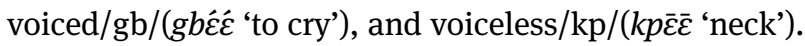

In many languages of Sub-Saharan Africa, such as Baoulé (Atlantic), nasal consonants are not fully phonologized, so that nasal stops are considered allophones of oral stops (Creissels 1994: 132). The same applies to nasal vowels, which in many languages do not correspond to nasal phonemes, but rather are part of combinations of the type VN or VNV (Creissels 1994). Mano, among many other Mande languages, has nasal vowels on the phonological level. In contrast, the 
Table 1: Mano vowels.

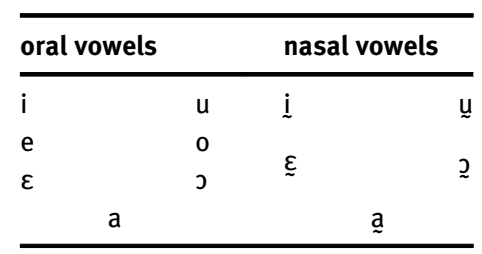

Table 2: Mano consonants.

\begin{tabular}{lllllll}
\hline & labial & alveolar & palatal & velar & velar labialized & labio-velar \\
\hline implosive & $\mathrm{b}$ & & & & & \\
unvoiced plosives & $\mathrm{p}$ & $\mathrm{t}$ & & $\mathrm{k}$ & $\mathrm{k}^{\mathrm{w}}$ & $\mathrm{kp}$ \\
voiced plosives & $\mathrm{b}$ & $\mathrm{d}$ & & $\mathrm{g}$ & $\mathrm{g}^{\mathrm{w}}$ & $\mathrm{gb}$ \\
unvoiced fricatives & $\mathrm{f}$ & $\mathrm{s}$ & & & & \\
voiced fricatives & $\mathrm{v}$ & $\mathrm{z}$ & & & & \\
oral sonorants & $\mathrm{w}$ & $\mathrm{l}$ & $\mathrm{j}$ & & & \\
nasal sonorants & $\mathrm{m}$ & $\mathrm{n}$ & $\mathrm{n}$ & $\mathrm{n}$ & $\underline{w}$ & \\
\hline
\end{tabular}

phonological status of nasal consonants in Mande is somewhat debatable. For half of the Southern Mande languages, such as Goo (Aplonova and Vydrin 2017), different varieties of Dan (Vydrin 2017; Vydrin and Kessegbeu 2008), or Mwan (Perekhvalskaya 2017), it is claimed that nasal stops are not phonologized and receive their nasal quality in nasal contexts, especially in combinations that have nasal vowels. In Mano, as in Tura (Idiatov and Aplonova 2017) and Beng (Paperno 2014), evidence suggests that nasal vowels do not trigger the nasalization of the consonants on the surface level, but rather that nasal consonants are phonologized. For a discussion of this, see Khachaturyan (2015: 10-11).

The Mano system also includes a syllabic nasal $/ \mathrm{y} /$ which can function as the nucleus of a syllable. It appears in the position of the only stem syllable or of two identical stem syllables $\mathrm{n}(\mathfrak{\eta})(\bar{\eta}$, first person singular pronoun of the past series, $\grave{\eta} \dot{\eta}$, first person singular negative auxiliary) or in the $\mathrm{CV}$ n position, where the syllabic nasal is preceded by a vowel (wō̄ 'tail', pè̀ 'forge'). The syllabic nasal always has a distinctive tone: mèǹ 'dream', mغ̀n 'behind'. In the former case, $\mathrm{n}(\mathrm{\eta})$, it is realized as a nasal stop that assimilates to the following consonant according to the place of articulation and, in certain cases, causes assimilation by nasality: $\bar{\eta}$ ló [n̄ñó] 'I went'. In the CVn position, it takes the form of a nasal vowel: a back vowel [u] if the previous vowel is back or central (wóń [wóú] 'tail') or a front vowel [i] if the previous vowel is front (pè̀n [pèi] 'forge'). Syllabic nasals are not uncommon in Sub-Saharan African languages: Creissels mentions a few, including Swahili, Igbo and some varieties of Manding (Creissels 1994: 57-64). 
For the representation of Mande phonology, I adopt the orthographic notation that is common for Mande (or, broader, African) linguistics: y stands for $/ \mathrm{j} / \mathrm{n} \mathrm{nw}$ stands for $/ \underset{\sim}{\mathrm{w}} /, \mathrm{kw}$ for $\mathrm{k}^{\mathrm{w}}$, gw for $\mathrm{g}^{\mathrm{w}}$, $\mathrm{kp}$ for $\overparen{\mathrm{kp}}$ and $\mathrm{gb}$ for $\overparen{\mathrm{gb}}$. $\mathrm{N}$ with a tonal diacritic corresponds to the syllabic nasal and $\mathrm{n}$ without a tonal diacritic corresponds to a nasal velar sonorant.

\subsection{Suprasegmental phonology}

Most of the languages of Sub-Saharan Africa and all Mande languages have tone (with the exception of some Mande varieties in contact with non-tonal languages, such as some varieties of Jalonke, Lüpke and Storch 2013). Mano has three level tones, low ( $k \grave{\varepsilon} \dot{\varepsilon}$ 'year'), mid ( $k \bar{\varepsilon}$ 'in order to'), and high ( $k$ ći 'refuse'). Extra-high tone is marginal in the system, as it appears only in ideophones, expressive adverbs,

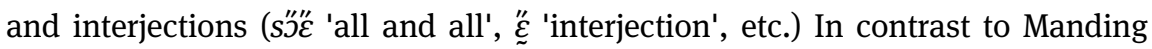
languages and some other languages with two tones, including Kpelle, downstep is not attested in Mano. Rich tonal inventories of three or more tones are typical for the Macro-Sudan belt, so Mano is no exception here (Hyman et al. 2018). The tonebearing unit is a vowel or a syllabic nasal; long vowels and diphthongs are considered combinations of phonemes. Complex tonal contours appear only on VV sequences. All tonal combinations are possible (see Table 3). Unlike some Southwestern Mande languages, such as Kpelle (Konoshenko 2014), no tonal spreading occurs in Mano, and grammatical tonal marking is hosted by specific words rather than phrases. Furthermore, Mano does not have stress accent, which is often (but not always) the case for tonal languages (Hyman 2009). Utterancelevel prosodic operations include the lowering of the tone on final vowels in affirmative utterances and a general downdrift.

The syllable seems to be of limited analytical salience (on that point, see Hyman 2011). By contrast, it is often claimed that Mande languages, including Mano and

Table 3: Tonal contrasts in VV sequences.

\begin{tabular}{|c|c|}
\hline LL & kàà 'reed' \\
\hline LM & kàā 'hook' \\
\hline LH & kàà '2PL negative auxiliary' \\
\hline$M L$ & kāà '2PL perfect auxiliary’ \\
\hline MM & $k \bar{a} \bar{a}$ 'crabe' \\
\hline $\mathrm{MH}$ & kpūú 'short' \\
\hline $\mathrm{HL}$ & káà ‘2PL conjoint series' \\
\hline HM & njَj ‘too much' \\
\hline $\mathrm{HH}$ & káá 'pour' \\
\hline
\end{tabular}


other Southern Mande languages, such as Guro (Kuznetsova 2007), possess "metric feet”, mono- or polymoraic units which have the following properties. First, specific phonotactic restrictions apply: vowel harmony, restrictions on the internal structure and on the inventory of intervocalic consonants. The domain of application of grammatical tones is the metric foot. This means that the rules of tonal assignment in grammatical contexts apply to the entire metric foot, rather than to a syllable or a mora. Finally, as a matter of statistical observation, non-derived lexemes tend to possess only one metric foot. Metric feet appear to be a special case of distributional asymmetries between the stem-initial and non-stem-initial syllables that are widely attested in the languages of the Macro-Sudan Belt (Hyman et al. 2018).

Metric feet in Mano can only occur as one of the following structures: V ( $\bar{e}$

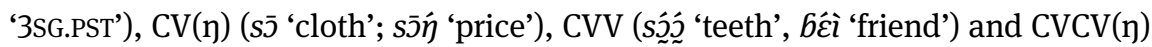
( $b \grave{\varepsilon} l \bar{\varepsilon}$ 'respect', $b \dot{\varepsilon} \bar{\varepsilon} \bar{\eta}$ 'tree sp.'). In the CVV structures, a combination of back and front vowels is disallowed, as well as nasal and non-nasal vowels, and vowels should be identical in CVCV structures. The intervocalic consonant should be either $/ \mathrm{n} /$, /1/, or $/ \mathrm{n} /, / 1$ is not allowed with nasal consonants $/ \mathrm{m} /, / \mathrm{n} /, / \mathrm{n} /, / \mathrm{nw} /$ in the initial position (yc̀lè 'manner', wòlò 'tear out') while $/ \mathrm{n} /$ is not allowed with $/ 6 /$, /l/, /y/ and /w/ in the initial position ( $m \bar{\varepsilon} n \bar{\varepsilon}$ 'snake', ywánà 'truth'), all other consonants in the initial position freely combine with both /l/ and /n/ in the intervocalic position. As a rule, grammatical tone applies only to one metric foot. Thus, the verb pélé 'to wash', which consists of one metric foot, according to the aforementioned parameters (CVCV structure; identical vowels; /1/ as an intervocalic consonant), takes the form with low tones on both vowels in the imperfective: pغ̀lè 'wash:IPFV' (1). However, the verb lóní 'to count' (2) consists of two metric feet of the CV structure, because the vowels are non-identical which violates the rule of vowel harmony. The grammatical tonal replacement applies accordingly: in the imperfective form, the grammatical tone applies only to the second vowel, which then takes the mid tone, lóni 'count:IPFV'. The same pattern of change applies to verbs of CV structure with lexical high tone: $b i$ 'to shine' and $6 \bar{\imath}$ 'shine.IPFV'(3).

(1) a. āà s̄o pélé.

3SG.PRF cloth wash

'She has washed the clothes.' (el.)

b. léc̀ s̄̄ pèlè.

3SG.IPFV cloth wash:IPFV

'She washes the clothes.' (el.)

(2) a. āà wélì lóní.

3SG.PRF money count

'She has counted the money.' (el.) 

b. léc̀ wélì lónī. 3SG.IPFV money count:IPFV
'She counts the money.' (el.)

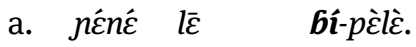
sun 3SG.EXI shine-INF
'The sun is shining.' (el.)
b. Jर́né léc̀
sun 3SG.IPFV shine:IPFV
'The sun shines.' (el.)

An interesting feature of Mano phonotactics is that combinations of back and front vowels within one metric foot, which are generally disallowed, are nevertheless possible after an (optionally) labialized velar consonant: $k^{(w)} \hat{\jmath} \grave{l}$ 'firewood', $k^{(w)} \bar{o}$ 'behind', and $\boldsymbol{k}^{(w)} \dot{\jmath} n \grave{\varepsilon}$ 'eggplant'. (The last word, $\boldsymbol{k}^{(w)} \dot{\jmath} n \dot{\varepsilon}$ 'eggplant', could potentially be analyzed as containing two monosyllabic feet. And yet the intervocalic consonant $/ \mathrm{n} /$ is characteristic of metric feet with the CVCV structure, so the interpretation in terms of a single metric foot is also possible.) It is unclear why a velar consonant should provide an exceptional environment for the violation of the general rule of vowel harmony. In the CVV combinations of this type, $\mathrm{V}_{2}$ is usually /i/, with one exception: $k^{(w)} \dot{\tilde{\varepsilon}}$ 'near'.' During fast speech, these combinations are pronounced with both front vowels and a

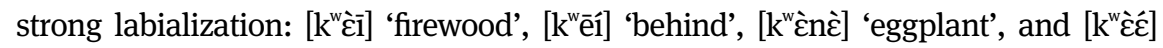
'near'. This type of process is especially salient in the Guinean dialects of Mano which are in contact with Guinean Kpelle in which a similar process is attested (Konoshenko 2017: 290). In Liberian Mano and Liberian Kpelle, the default variant seems to be with a back - front combination and the labialization of the velar consonant is much weaker (e. g., in Liberian Mano [kj̀i] 'firewood'), which suggests a micro-areal phenomenon.

\section{Morphosyntax of NPs}

Mano has relatively limited nominal morphology, with only one productive derivational suffix (-là, suffix of abstract nouns) and two tonal forms: high tone forms used in particular when the noun is followed by a demonstrative (lēé 'woman', léé $w \bar{\varepsilon}$ 'this woman') and low tone construct forms. The term "construct forms" was coined by Creissels to designate a type of head marking which includes, but is not

2 The only CVV word that does not begin with a velar consonant and that has a combination of a front and a back vowel is s'J̌c ‘all'. It is an emphatic adverbial quantifier used with the quantifier sén 'all'. It is unusual in yet another respect: it has an extra-high tonal contour that is typical for expressive entities. See above for additional information on this. 
limited to, the construct state forms introduced in Semitic linguistic (Creissels 2017). Construct forms are used in Mano as heads of noun phrases with certain types of dependents, excluding possessors, but including nominal or verbal attributes. In (4), the lexical form of 'woman' is lēe, the construct form is lèè in (5) the lexical form of 'person' is $m \bar{i}$, the construct form is mì.

$$
\begin{aligned}
& \text { gí lèè } \\
& \text { stomach woman:CSTR } \\
& \text { 'pregnant woman' (el.) }
\end{aligned}
$$

$\begin{array}{lllll}\text { dj̀ } & \text { wálà } & \text { lé } & \text { là } & \text { mì } \\ \text { stop:NMLZ } & \text { God } & \text { mouth } & \text { on } & \text { person:CSTR } \\ \text { 'prophet' (nat.) } & & & \end{array}$

Construct forms are typical in Mande, particularly in the Southern branch, but these forms are also attested in Soninke (Creissels 2016). Construct marking is often expressed by a low tone and is likely to have existed in proto Mande (Creissels pers. comm.). On replacive tonal patterns in Mande, including the construct form, see Green (2018) and Konoshenko (2018).

Adjectival morphology includes the derivational suffix of adjectives $(-z \grave{\varepsilon})$, as well as reduplication with values of intensity and plurality (Section 4.3). Numerals can also reduplicate with a distributive meaning. However, nouns and verbs do not reduplicate. The word order in the noun phrase is typically a genitival modifier (an alienable or inalienable possessor, as well as the dependent in the constructions with construct forms), followed by the head noun, and followed by an adjective, a numeral, and a determiner. I present a detailed analysis of several properties of Mano nominal morphosyntax: rich pronominal paradigms (Section 4.1), inclusory constructions and pronouns (Section 4.2), the expression of plurality (Section 4.3) and the possessive split (4.4).

\subsection{Pronominal paradigms}

A distinctive feature of most Southern and Southwestern Mande languages is their rich pronominal paradigms that include several syntactic series of personal pronouns, as well as several series of auxiliaries which index a subject's person and number. Personal pronouns typically distinguish between non-subject pronouns that occur in most argument positions (an inalienable possessor, $6 \mathrm{a}$, direct object, $6 \mathrm{~b}$, or an argument of postposition), possessive pronouns that express alienable possession (ex. 6c) and emphatic pronouns used in non-argument positions (ex. 6d). Besides these three positions, Mano also has high tone pronouns, a functional parallel of the high tone nominal forms mentioned above, which are used with demonstratives and 
with focalization markers (example 6e), and the inclusory pronouns (example 6f), the most typologically unusual of all, which will be discussed in Section 4.2. Mano does not have pronouns that are used in the syntactic position of the subject but has auxiliaries agreeing in person and number with the subject (see Section 6.2). Personal pronouns in Mano are listed in Table A1 of the appendix.

(6) a. kō dàa

1PL father

'our father' (nat.)

b. Pèé $\bar{e} \quad \boldsymbol{k} \overline{\boldsymbol{o}} g \grave{\sim}$.

P.N. 3SG.PST 1PL see

'Pe saw us' (el.)

c. kò ká

1PL.Poss house

'our house' (el.)

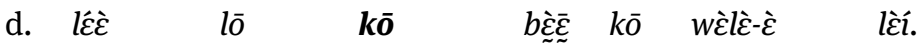

3SG.IPFV go:IPFV 1PL.EMPH too 1PL get.up-GER sky

'He will raise us, too, to the sky.' (nat.)
e. kó té kō yàá kélè zèe wāā.
1PL.H ATT 1PL.EXI sit>GER>with room here BKGR
'We who are sitting in the church here...' (nat.)

f. kò Pèé

1PL.IP P.N.

'me and Pe (lit.: we [including] Pe)' (el.)

\subsection{Inclusory constructions and pronouns}

Inclusory constructions are a type of conjunction strategy that consists of an adjunction of two sets. These involve the whole set of participants, or the superset, which are usually represented by an inclusory pronominal, and a subset of participants that is expressed by a pronoun or a full NP (Lichtenberk 2000; Haspelmath 2004: 25-26), as in Mano below:

$\begin{array}{llllllll}\text { INỳ } & \text { nàà } & \boldsymbol{k} \mathbf{o} & \boldsymbol{6} \overline{\mathbf{i}} & \text { kó } & \text { kō fòtóò sí. } \\ \text { 1SG.IPFV } & \text { want:IPFV } & \text { 1PL.IP } & \text { 2SG.EMPH } & \text { 1PL.CONJ } & \text { 1PL } & \text { photo take } \\ \text { 'I want that you (sg.) and I OR you (sg.) and we, we take a picture of us (lit.: } \\ \text { I/we [including] you (sg.) we take our photo).' (el.) }\end{array}$

In (7), $k \grave{o}$ 'we' refers to the entire set of participants, while $6 \bar{\imath}$ 'you' refers to a subset. Another subset, implicitly referred to by kò 'we', is either the speaker, or the 
speaker with some other participants. The literal meaning of the construction is 'we [including] you (sg.)' and two possible interpretations: either you (sg.) and I, or you (sg.) and we. The whole group of those whose picture is to be taken is indexed again by the non-subject pronoun $k \bar{o}$ in $k \bar{o}$ fòtóò 'our picture'.

Several Southern and Southwestern Mande languages have inclusory constructions. Although inclusory pronouns are especially common in Austronesian languages (Lichtenberk 2000; Bril 2004; Lee 2011) and languages from several language families spoken in Australia (Singer 2001), they are also attested in European languages, such as French dialects and some Slavic languages, including Polish and Russian (Tesnière 1951). What makes the Mande family typologically outstanding is that inclusory pronouns in some of the Mande languages, including Mano, are represented by a separate series ${ }^{3}$ (see Table A1 of the appendix). This property does not exist outside this language family (for more detail on inclusory constructions in Mande, see Khachaturyan 2019).

\subsection{Expression of plurality}

In Mano, when a noun that has a non-human referent is unmarked for number, it can correspond to one or many entities in the world. Thus, the form $g b{ }_{\sim}^{a}$ 'dog' can denote one or several dogs. The number of referents can be specified by specialized number determiners, number words (gbá vj̀ dog PL 'dogs') or numerals (gbå dōó 'one dog', gbáa pèèlē 'two dogs'). The typological literature claims that this unmarked form expresses general number (Corbett 2000: 9-10). In contrast, for human referents, an unmarked form is usually interpreted as sin-

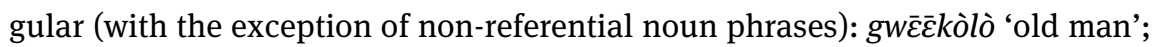

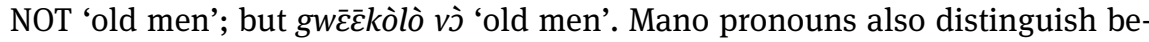
tween singular and plural forms. This means that Mano referents split into two categories depending on their position on the Animacy Hierarchy (Smith-Stark 1974): pronouns, as well as noun phrases that denote humans distinguish between singular and plural, while an unmarked form of non-human referents has a general interpretation.

3 The fact that inclusory pronouns coincide in form with possessive pronouns notwithstanding, their syntactic behavior is distinct, each covering a specific syntactic domain. There are other cases of homonymy in plural pronominal markers, such as in the basic series and in non-portmanteau past series of auxiliaries, which are clearly two distinct syntactic series. Most importantly, inclusory pronouns do not coincide in form with other pronouns which, crosslinguistically and in Mande languages, are expected to have the inclusory function: such as the emphatic or the basic series. 
Plurality in Mano is most often expressed by the number words vì and nì. The vì marker combines with all referents except kinship terms and pronouns and its semantic interpretation is additive plurality (' $\mathrm{X}$ ' + ' $\mathrm{X}$ ' + ' $\mathrm{X}$ '...). Nì combines with all types of referents without restriction, but the semantic interpretation is not the same for all nouns (see below). This means that the Animacy Hierarchy again plays a role, the division occurring in a different position of the hierarchy, separating kin from other human referents (on that point, see Dahl and Koptjevskaja-Tamm 2001).

The nì marker is typologically rather rare semantically, as it combines the values of associative plurality and distributive plurality, which together I call "non-additive plurality". The former indexes a set of objects that includes the referent of the host noun and some other objects connected to it (Daniel 2000: 4). Typically, the associative marker is used with human referents (Sèe nì 'Se and his family/friends'), but it also can be used with other types of referents (yízólóyàà nì 'jaundice and other sicknesses', see also example 8b). The associative marker is typically used with proper names, pronouns and kinship terms, but can also be used with other nouns. Distributive plurality, in turn, indexes “...the separation of members of a group, whether entities, events, qualities or locations. Each is considered distinct in space, sort or time" (Corbett 2000: 111). In the distributive value, the marker is often combined with mass nouns (9b), but it can also be used with discrete entities (mōtōò nì 'motorbikes here and there'). While both values, associative and distributive, are known from descriptive and typological literature, their combination in one marker appears to be cross-linguistically rare.

The following examples contrast additive and non-additive plurality. Example (8a) illustrates the usage of nj̀ 'catfish' with vò triggering an additive reading. Example (8b) shows the usage of the same noun with nì and this triggers an associative reading. Example (9a) illustrates the incapability of the mass noun wèn 'salt' to combine with the additive marker vj. Finally, in (9b), the same noun combines with the marker nì, triggering a distributive reading.

(8) a. nj̀̀ v̀̀

Catfish PL

'(several) catfish' (el.)

b. nò̀ nì

catfish PL

'catfish and company' ('catfish and them' in some varieties of English)

(`several catfish)' (nat., modification)

(9) a. *wè̄ vò

salt PL

intended reading: 'salts' 
b. wèn nì, súò nì, $p \bar{\varepsilon} \quad \bar{a} \quad n \bar{a} \bar{a}$ lōà $\quad$ vò kèlè salt PL pepper PL thing every find woman.PL PL hand '(Different types of) salts, (different types of) peppers, everything that he found in the woman's hands...' (nat.)

While number words are the most common means to express plurality, a few nouns express plurality (with or without a number word) by an irregular inflection and this can be considered a case of suppletion (Veselinova 2006; Corbett 2009). These nouns include names of humans and kinship terms with a most general meaning

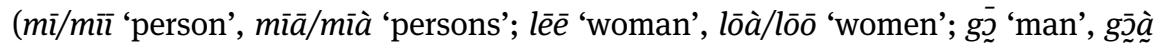

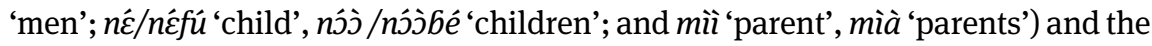
noun $p \bar{\varepsilon}$ 'thing(s)', $p \bar{\jmath} \grave{j} / p \bar{\jmath} \grave{j} b e ́$ 'things'. Suppletion displays some patterning: the labialization of mid-low or mid-high vowels and an additional formant: $-\grave{a} /$ - $\underset{\sim}{a}$ or 6é; some part of the nominal stem remains unvaried - minimally, the initial consonant. As a consequence, nominal suppletion in Mano could be characterized as "weak" (Dressler 1985) or "partial” (Corbett 2009).

Finally, plurality can also be expressed in adjectives. Of Mano adjectives, ${ }^{4}$ approximately one-half can undergo reduplication and this includes most non-derived adjectives. While non-reduplicated adjectives can freely combine with the singular/ general (10a) or plural forms of nouns (10b), some reduplicated adjectives combine only with the plural forms of those nouns that distinguish between singular and plural forms (10c versus 10d) and trigger a plural reading when combined with nouns that do not distinguish between such forms, which is illustrated in (11). These reduplicated forms express nominal plurality. For some other adjectives, the value of reduplication is to express quality intensity (12) or both intensity and plurality (13).
a. $p \bar{\varepsilon} \quad t \bar{\imath}$
thing black
'black thing/black things' (el.)
b. $p \bar{j} \grave{j} \quad t \bar{\imath}$
thing.PL black
'black things' (el.)
c. ${ }^{*} p \bar{\varepsilon} \quad t \bar{\imath} \sim t \bar{\imath}$
thing black PL
intended reading: 'black things'
things.PL black PL
'black things' (el.)
d. $p \bar{j} \grave{j} \quad t \bar{\imath} \sim t \bar{\imath}$

4 Other entities that can reduplicate are numerals and some quantifiers, such as sén 'all'. On the reduplication of numerals, see Khachaturyan (2015: 37). 
(11)
cloth black
'black cloth/black cloths' (el.)
a. $s \bar{\jmath} \quad t \bar{\imath}$
b. $s \bar{\jmath} \quad t \bar{\imath} \sim t \bar{\imath}$
cloth black PL
'black cloths' (el.)

(12) a. lēē kpàlé-zè

woman strange-ADJ

'a strange woman' (el.)
b. lēe kpàlé kpàlé-zè
woman strange _INT-ADJ
'a very strange woman' (el.)

(13) a. yúlí kpàlā

tree big

'big tree' (el.)
b. yílí kpàlā kpàlā
tree big RED
'very big trees' (el.)

While adjective reduplication is not uncommon cross-linguistically, its typical value is the intensity of the quality that is expressed by the adjective (as in Hindi, Singh 2005; or Turkish, Sofu 2005). However, adjective reduplication in Southern and certain Southwestern Mande languages typically expresses plurality, a semantic property that is proper to noun phrases and may be expressed in adjectives when they are targets of agreement (Vydrine 2004). The plural value of adjective reduplication may be an areal feature that Southern Mande languages share with Kwa: the same phenomenon is observed in Akan (Winkler and Obeng 2003) or Baoulé (Creissels and Kouadio 1977: 274). ${ }^{5}$ Moreover, the adjective may be the only locus of the expression of plurality. This is because Mande, like Mano in particular, has few nouns that have plural forms. Thus, in cases such as (11b), the apparent controller of the agreement is unmarked for number.

In addition to reduplication, plurality in adjectives can be expressed by a tonal form. This applies to those adjectives that are reduplicated but whose non-reduplicated counterpart does not exist. Thus, the adjective in (14), yj́sjyj̀s j̀ 'dirty', does not exist in a non-reduplicated form ( ${ }^{*} y$ ýsó). For adjectives such as the one in (14), the basic tonal pattern that is High-Low changes to High-High, so that the overall morphological process could be considered a case of partial reduplication: of a tonal pattern but not a segmental pattern.

5 I would like to thank Denis Creissels for this observation. 


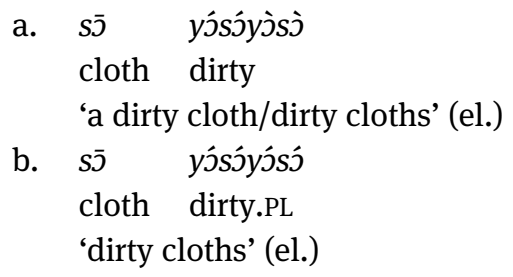

In addition, three adjectives are pluralia tantum, which only occur with plural referents: dòló 'similar.PL', kènéċ 'small.PL', and kélékélé ‘small.PL' (15). Other adjectives occur in Mano that mean 'small': bén, tíikpé, néc, and péétí, so the adjectives kènćc̀ and kélékélé could be considered suppletive plural forms. ${ }^{6}$ The adjective gbj́kò '1. numerous, 2. elderly, 3. fat', when reduplicated, retains only one meaning: gbj́kògbj́kò 'fat.PL'. The adjective gbưu ù has the meanings '1. other, 2. certain, 3. different.PL', it is in the latter meaning that it behaves similar to a plurale tantum.
a. ${ }^{*} p \bar{\varepsilon} \quad k \dot{n} n \varepsilon \dot{\varepsilon}$
thing small.PL
intended reading: 'small things' (el.)
b. pj̄j kènéc̀
thing.PL small.PL
'small things' (el.)

Thus, number agreement applies between nouns and adjectives. Those nouns that do not distinguish between number forms, as in $(11,14)$ and plural-marked nouns (10b, 10d), combine with both plural-marked and plural-unmarked adjectives. In contrast, when nouns do distinguish between number forms and are unmarked for plurality, they combine only with plural-unmarked adjectives (10a, 10c and 15).

\subsection{Inalienable vs alienable possession}

Mano resembles most other Mande languages in that it has two types of possessive construction, inalienable and alienable. In the case of a pronominal possessor, a non-subject pronoun is selected, as in (16a). Example (16b) illustrates a construction that consists of a possessor juxtaposed to the possessum in absence of

\footnotetext{
6 Suppletion in the number form of adjectives is rather rare across languages, although not nonexistent. Vafaeian (2013) mentions Halkomelem (Salishan), Kashaya (Pomo), and Tariana (Arawak), whereas a somewhat different type of adjectival suppletion is attested in Swedish. Suppletive number forms of adjectives have been attested in Lavukaleve (Papuan isolate, Terrill 2003: 52-53), but note also that the number morphology of adjectives in the language is much more developed and regular as compared with Mano.
} 
any formal marking. The second type consists of the possessor expressed by a possessive pronoun (17a), optionally preceded by a noun phrase (17b). Non-subject and possessive pronouns are clearly marked with a tonal contrast: non-subject pronouns have the mid-tone $(\bar{\eta})$ and possessive pronouns have low tone $(\grave{\eta})$.

$$
\begin{array}{lll}
\text { a. } & \bar{\eta} \quad k \bar{\imath} \\
& \text { 1SG skin } \\
& \text { 'my skin' (el.) } \\
\text { b. } & \text { Pèé } \quad k \bar{\imath} \\
& \text { P.N. skin } \\
& \text { 'Pe's skin' (el.) }
\end{array}
$$

$$
\begin{array}{lll}
\text { a. } & \bar{\eta} \quad k \bar{l} \\
& \text { 1SG.POSS shoes } \\
& \text { 'my shoes' (el.) } \\
\text { b. } & \text { Pèé là } \quad k \bar{l} \\
& \text { P.N. 3SG.POSS shoes } \\
& \text { 'Pe's shoes' (el.) }
\end{array}
$$

An alienable possessor can be added to combinations of the former type:

$$
\begin{aligned}
& \text { Pèé là wì̀ kpákāâ } \\
& \text { P.N. 3SG.Poss animal leg } \\
& \text { 'animal leg belonging to Pe' (el.) }
\end{aligned}
$$

The existence of the distinction between alienable and inalienable possession is far from being cross-linguistically unusual (Nichols 1988; 1992; Dahl and KoptjevskajaTamm 1998), but several aspects of the distinction need to be clarified.

First, the class of inalienably possessed nouns in Mano is much broader than the typological prototype, which includes body parts and kinship terms, spatial terms, and some significant parts of objects and basic objects of material culture, such as cattle (Nichols 1988). Mano nouns that are inalienably possessed include, of course, kinship terms ( dàā 'father', lēkè 'younger sibling), but also other terms of social relations that are not related to kinship: bèa 'contemporary, person of the same age group’, tóómá ‘namesake’, gèlè ‘enemy’, gờa ‘equal', kélá ‘witness', and yókò 'enemy'. By comparison, the noun nć 'child' is alienably possessed. Body parts, excretions, physiological liquids are also inalienably possessed ( $z \grave{o}$ 'heart', sèe 'nail', and líà 'blood'), together with some parts of objects (tō 'source', gbáa á 'ceiling', and gbj̀lś 'frame'). Not surprisingly, spatial terms, some of which give rise to postpositions, also belong to the inalienably possessed class (yàlà 'place', wì 'lower part'). This class also includes the names of measures, groups and assem-

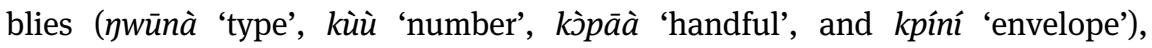


attributes, sicknesses (nónj́ 'taste', tòn̄̄ 'benefit', fàná 'force', zùō 'paralysis', t’́

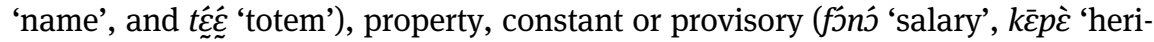
tage', sāmā 'gift', sālà 'salary’, wòlj̀ ‘sleeping place', and kón’́ 'food'), some names of dishes (báá '(rice) porridge', fili 'pilaf') and names that designate the age or sex of an animal (ḡ̄ 'male', $m \bar{\sim}$ 'female', and nònś ‘young'). Finally, another subclass of inalienably possessed nouns includes names of actions that occur in $\mathrm{N}+\mathrm{V}$ com-

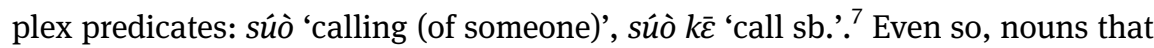
denote objects of material culture are never inalienably possessed.

While it is well established that the class of inalienably possessed nouns can include some non-prototypical items, in Mano, every third inalienably possessed noun could be considered non-prototypical. Thus, the repartition between the two classes is often arbitrary. For example, the noun fili 'pilaf' denotes a dish consisting of rice mixed with spices and either fish or meat. The noun is inalienably possessed: wì fili 'pilaf with meat'. However, the word bòo 'sauce', which is always distinguished by the type of the main ingredient, is alienably possessed. Should the main ingredient be specified, a different construction is used that has a head in the lowtone construct form: béiléćbòò < cassava + leaf + sauce:CSTR > 'cassava leaf sauce'.

Another interesting feature of the grammar of possession in Mano is that some inalienably possessed nouns are obligatorily possessed, that is, they always occur with a possessor (approximately 75\% of all inalienably possessed nouns), and some are optionally possessed, at least in certain contexts. ${ }^{8}$ The distribution into these two classes also seems arbitrary. Let us consider two synonyms, sālà and fóñ́ 'salary’. Both are inalienably possessed: à sālà, à fónó 'her salary’. Nonetheless, sālà can be used without a possessor, while fóñ́ cannot:

$$
\begin{array}{llllll}
s \bar{a} l a ̀ & t \hat{\varepsilon} & z \grave{e} \bar{e} & w \bar{\varepsilon} & l \bar{\varepsilon} & s \grave{\varepsilon} . \\
\text { salary } & \text { ATT } & \text { here } & \text { BKGR } & \text { 3SG.EXI } & \text { good } \\
\text { 'The salaries (which are) here are good.' (el.) }
\end{array}
$$

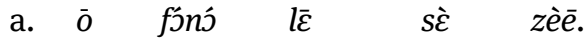
3PL Salary 3SG.EXI good here
'The salaries are good here (lit.: their salaries)' (el.)
b. *fónó $l \bar{\varepsilon} \quad s \dot{\varepsilon} \quad z e ̀ \bar{e}$.
salary 3SG.EXI good here
Intended reading: 'The salaries are good here.'

7 On the relationship between the possession and valency of complex predicates, see Khachaturyan (2017).

8 A similar distinction is observed in Tariana (Aikhenvald 2003: 127-128). 


\section{Verb phrase}

Many of the cross-linguistically unusual properties of Mano verb phrasal syntax are related to its peculiar S-AUX-O-V-X word order (Section 5.1), which is typical of Mande, and its likely diachronic origin is in verbal nominalization, which makes the present-day expression of nominalization particularly interesting. The identical treatment of inalienable possessors and direct objects in Mano makes it difficult to classify the language with respect to the typology of the argument treatment in nominalizations (Section 5.2). Postverbal arguments, and in particular, postpositional phrases, do not have the same level of embedding as direct objects. The distinction between direct objects and obliques is evident from nominalization. Unlike many other Mande languages, however, Mano makes use of a curious clause-level nominalization marker, which allows nominalization to occur with postpositional phrases (Section 5.3). Finally, Mano and other Mande languages exhibit properties of radical P-alignment and make extensive use of Plability, which makes the family rather unusual typologically (Section 5.4).

\subsection{Word order}

Mano and other Mande languages observe a fixed S-AUX-O-V-X word order (21, 22), with the direct object preceding the verb, while all other arguments, expressed by postpositional phrases, follow it (Creissels 2005; on the SOVX word order as an areal feature of the Macro-Sudan Belt, see Güldemann 2008a). Unlike many languages of Sub-Saharan Africa, the Mande languages do not have double-object constructions in which both the recipient and the theme are expressed as patients of a prototypically transitive verb (Creissels 2018).

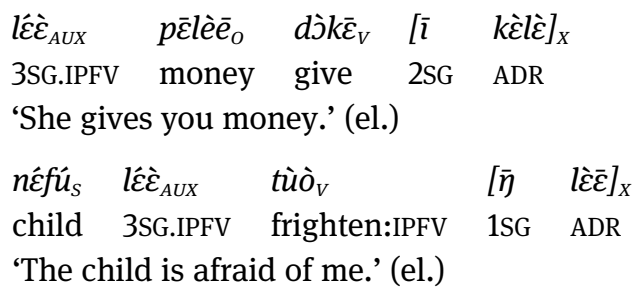

The Mande word order S-AUX-O-V-X probably emerged from a reanalysis of prior nominalizations which changed the typologically more common VOX word order to OVX (the analysis is presented in Nikitina 2011 along with an overview of alternative viewpoints). According to the hypothesis proposed by Nikitina, nominalization constructions were reinterpreted as verb phrases as part of finite constructions, and in particular, the patients expressed by the inalienable possessors 
preceding deverbal nouns were reinterpreted as direct objects. This hypothesis explains the striking parallel between the syntax of verb phrases and possessive nouns phrases, the fact that postpositional phrases display a distinct behavior in nominalization (see below), and the aforementioned absence of double-object constructions. Reanalysis of prior nominalizations into finite clauses is not uncommon cross-linguistically (Yap et al. 2011); in particular, the emergence of a typologically rare word order as a result of reanalysis of nominalizations was claimed for Cariban languages (Gildea 1998).

\subsection{Nominalization}

Mano has three nominalization forms: zero-marked, gerund (- $\grave{a}$, the vowel assimilates to the preceding vowel) and a low-tone form. They are used in all positions that are typical of nouns, such as the arguments of verbs and postpositions and may be used with derivational morphology, such as the adjectival suffix $-z \grave{\varepsilon}$, as illustrated in (30d). Unlike the former two forms, the low-tone form is used whenever the verb is nominalized with a postverbal argument adjacent to it. The distribution of nominalization forms in different contexts is presented in Khachaturyan (2015: 145-156).

The argument expression in nominalization roughly follows the PossessiveAccusative type suggested by Koptjevskaja-Tamm (1993): while the P argument is expressed precisely the same as the direct object in finite constructions $(25,26)$, the S argument is expressed like an inalienable possessor (24) and the marking of the A argument is identical to the marking of the alienable possessor (26).

(23) āà $n \bar{u}$.

3SG.PRF come

'He has come.' (el.)

(24) à $n \bar{u}-\grave{a} \quad l \bar{\varepsilon} \quad s \grave{\varepsilon}$.

3SG come-GER 3SG.EXI good

'His coming is good.' (el.)

(25) $\quad \bar{a} a ̀ \quad s \underset{\sim}{a} \bar{a} \quad k \bar{\varepsilon}$.

3SG.PRF work do

'He has worked (lit.: he has done work).' (el.)

(26) là $\quad s \underset{\sim}{a} \bar{a} \quad k \bar{\varepsilon}-\grave{\varepsilon} \quad l \bar{\varepsilon} \quad s \grave{\varepsilon}$.

3SG.POSS work do-GER 3SG.EXI good

'His working is good (lit.: his doing work is good).' (el.) 
The situation is complicated by the fact that in all contexts, the marking of the direct object is identical to the marking of the inalienable possessor (6a-6b). This blurs the distinction between the Possessive-Accusative and the Sentential type in the case of the direct object. The complication can be explained by the aforementioned hypothesis that verb phrases in Mande derive from nominalizations.

Mano is reminiscent of Austronesian languages and in particular of the Tolai language, in terms of the possessive split in the expression of subjects and the identical coding of inalienable possessors and direct objects (Foley 2014). Unlike Tolai, in which the possessive split is motivated by the degree of agentivity of the subject, it is motivated in Mano purely by argument roles (on a similar subject, see van Lier and van Rijn 2013). In addition, in Mano nominalizations, intransitive subjects are expressed in the same manner as direct objects. In Southwestern Mande, the situation is similar: the intransitive subjects are treated as direct objects in certain grammatical constructions, including nominalizations (Konoshenko 2017: 333). This situation is analyzed as an instance of (split) ergative/ absolutive alignment (Vydrin 2011).

\subsection{Postverbal arguments and clause-level nominalization}

Postverbal and preverbal arguments do not have an identical syntactic relationship with the verb, which can be observed by their behavior in nominalizations. When the verb is nominalized, the nominalized constituent always includes the direct object when the verb is transitive, but not necessarily the oblique argument:

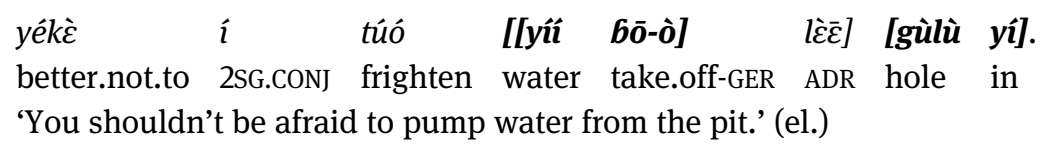

The verb in the example above, túo 'frighten, to be afraid', has a postpositional argument headed by the postposition $l \grave{\varepsilon} \bar{\varepsilon}$. The postpositional phrase contains the nominalized verb phrase yí $6 \bar{o} o ̀$ 'pump water', in which the verb is marked by the suffix - $a$. The verb $6 \bar{o}$, in turn, also has a postpositional argument, gùlù yí 'from the pit (lit.: in the pit)', but this argument is situated outside the nominalized verb phrase and is separated from it by the postposition lèे .

Similar behavior of postpositional phrases in Wan, another South Mande language, led Nikitina (2009) to conclude that postpositional phrases in Wan are situated in the adjunct position to the IP (see also Nikitina 2018). A crucial difference between Mano and Wan is that in Wan, postpositional phrases are 
typically extraposed from the nominalized verb phrase, ${ }^{9}$ while in Mano, a verb can be nominalized together with its postpositional argument:

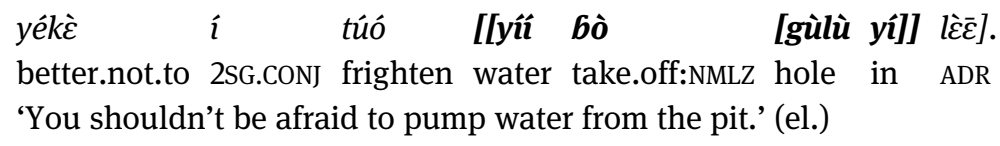

It is important to note that in (28), which is similar to (27) in all respects but the position of the postpositional phrase, the form of the verb $6 \bar{o}$ 'take off' is also different. While it occurs in the gerund form in (27), it occurs in (28) in the special low-tone nominalization form that is used in nominalizations with oblique arguments. Dan-Gweetaa and Kla-Dan, languages closely related to Mano belonging to the Dan language cluster, also have a low-tone form that functions similarly (on Dan-Gweetaa, see Vydrin 2008).

Lexicalized nominalizations often occur with obligatory postverbal arguments, including postpositional phrases. Example (29a) is a finite construction with the verbal complex zò gélé <heart-burn> 'to be angry'. In (29b), the verbal complex is lexicalized to form the noun zògèlègé 'anger'. It is important to note the low tone of the head verb gèlè 'burn:NMLZ'. The argument of the inalienably possessed noun gé 'stomach' is omitted. Examples (30a) and (30b) are similar with the verbal complex $z \grave{o} d \bar{\jmath}<$ heart-lay> 'to trust' and the lexicalized nominalization zòdj̀amò 'belief, faith'; note the low tone in (30b) on dj 'lay:NMLZ'. The argument of the postposition in (30b) is represented by the dummy pronoun $\grave{a}$. For the nominalization in (30c), the object of belief is precise, wálà 'God'. Lexicalized nominalization can further undergo adjectivization with the suffix $-z \grave{\varepsilon}$, as in (30d), zòdjàmòzè 'faithful'.

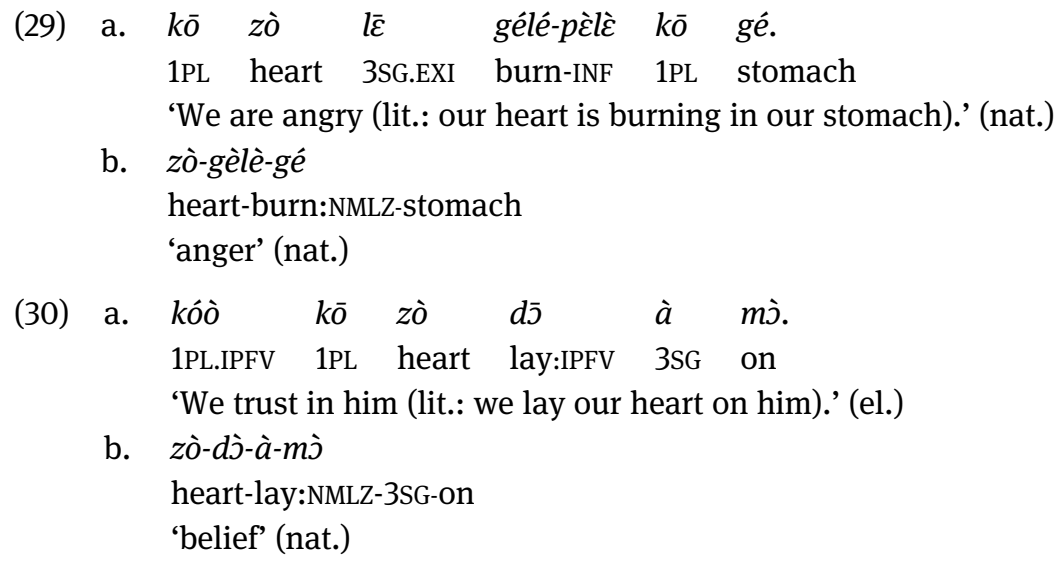

9 In nominalized intransitive verbs in Wan, certain oblique arguments can also be situated in the inalienable possessor position. See Nikitina (2008). 


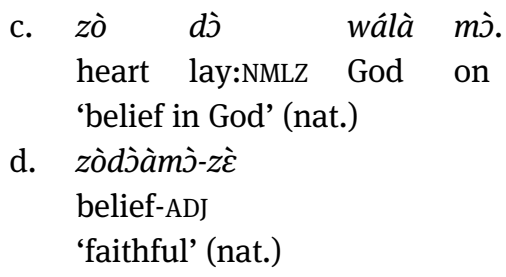

In Mano, the nominalization form is used whenever the verb is nominalized with a postverbal element, be it a postpositional phrase or an adverb. Furthermore, it can be used even with a specific type of finite predication, namely, a conjoint construction that expresses either a consecutive action, or a simultaneous action (on conjoint constructions, see Section 7.1):

$$
\begin{aligned}
& \text { a. } \bar{e} \quad n \bar{u} \text { áà } p \bar{\varepsilon} \quad s e ́ n \text { wì. } \\
& \text { 3SG.PST come 3SG.JNT thing all break:JNT } \\
& \text { 'He came and broke everything.' (el.) } \\
& \begin{array}{lllllll}
\text { b. [nù } & \text { áà } & p \bar{\varepsilon} & \text { sén } & \text { wì] } & \text { wó } & \text { sì. } \\
\text { come:NMLZ } & \text { 3SG.JNT } & \text { thing } & \text { all } & \text { break:JNT } & \text { COP.NEG } & \text { good } \\
\text { 'To come and break everything is not good.' (el.) } & &
\end{array}
\end{aligned}
$$

In (31b), the subject of the copula sentence is the construction nù áà $p \bar{\varepsilon}$ sén wì, which contains the verb $n \bar{u}$ 'to come' in the low-tone nominalization form and a finite predication áà p $\bar{\varepsilon}$ sén wì 'he breaks everything' with a third person singular auxiliary áa.$^{10}$ As the nominalized constituent with the low-tone form can contain finite clauses, this form should be considered a marker of clausal nominalization, in contrast to the VP nominalization marked (in certain contexts) by the gerund form, as in (22). While nominalization with clausal dependents has nothing unusual (see nominalization in English with complement clauses: [Learning that everyone should be treated with respect] was hard for Mary), it is worth noting that in Mano, such dependents require the use of specific nominalization marking. To conclude, nominalizations in Mano are characterized by mixed syntax with partly nominal (expression of direct objects as inalienable possessors) and partly verbal properties (the expression of verbal complements and adjuncts; on mixed syntax of Mande nominalizations, see Nikitina 2008; the issue from a broader perspective is addressed in Lefebvre and Muysken 1987).

10 The only finite construction that occurs with nominalization is what is referred to as the conjoint construction, which is pragmatically subordinated, used in clause-chaining always following some situational anchor (see Section 7.1) and therefore should be situated lower on the finiteness scale than other constructions, which are freely used in main clauses. 


\subsection{Transitivity and lability}

Mano does not have any morphological marking of derived (in)transitivity, which can also be observed in several other Southern Mande languages, such as Guro or Beng (Kuznetsova 2011; Paperno 2014). Some other Southern languages, such as Kla-Dan (Makeeva 2011), at least, have causative markers, which is also a typical trait of Western Mande, such as Kakabe (Vydrina 2011) or Mandinka (Creissels and Sambou 2013). To express valency changing, Mano has two procedures: one is analytic, such as the impersonal or reflexive construction, the other is lability, with a morphologically unmarked variation of argument structure, in which the verb can appear in the same form in the transitive or intransitive constructions. A striking feature of Mande, and Mano in particular, is the widespread P-lability, a variation in the argument structure in that the patientive participant occupies the position of the subject. The following example illustrates morphologically unmarked causal versus noncausal alternation in which the verb 'to (make) fall' is used in a transitive construction and an intransitive one with no overt morphological marking.
a. $n \hat{\varepsilon} \quad \bar{e} d \grave{a}$.
child 3SG.PST fall
'The child fell.' (el.)
b. kóò kò né dà ì lìे.
3SG.EXI 1PL.POSS child fall 2SG ADR
'We are presenting our child to you (lit.: we are making our child fall to you).' (nat.)

A far more cross-linguistically rare feature is passive lability in which the semantics of the verb have strong agent-oriented components. This is in contrast to an earlier prediction by Haspelmath (1993) that this type of lability cannot occur, it appears to be typical for Mande (Cobbinah and Lüpke 2009; Vydrina 2011; Creissels 2014), but also occurs elsewhere, such as in some Daghestanian and Austronesian languages (for a typology of lability, see Letuchij 2013).
a. òó gbāā wòlj̀
sj̀l̄̄
$6 \bar{o}$.
3PL.NEG NEG sleeping.place getting implement
'They did not obtain a sleeping place.' (el.)
b. wòlj̀ lèce gbāa sj̀
sleeping.place 3SG.NEG NEG getting implement
'The sleeping place was not obtained.' (nat.)




\section{Tense, aspect, modality and polarity}

Mano predications are divided into two major types: copula clauses, in which the head is a copula, and auxiliary clauses in which the auxiliary is the head of the clause. Auxiliaries express TAMP and function as a site of subject indexation. Nonetheless, the auxiliaries are not the only markers of TAMP. As it is typical for languages of Sub-Saharan Africa (Welmers 1973: 343), the expression of TAMP values in Mano is not located in specific markers. Instead, it is expressed by an entire construction that contains auxiliaries and predicative markers, particles, adverbs and verbs in a particular morphological form. Thus, (34) contains the durative construction which has an existential 3SG auxiliary $(l \bar{\varepsilon})$ and a verb with the infinitive suffix -pغ̀lè.

$$
\begin{aligned}
& l \bar{\varepsilon} \quad n \bar{u}-p \grave{\varepsilon} l \grave{\varepsilon} . \\
& \text { 3SG.EXI come-INF } \\
& \text { '(S)he is coming.' (el.) }
\end{aligned}
$$

Example (35) contains the negative perfective and there is a negative 3SG auxiliary

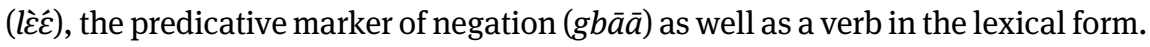

$$
\begin{array}{lll}
\text { lèc } & \text { gbāa } & n \bar{u} . \\
\text { 3SG.NEG } & \text { NEG } & \text { come } \\
\text { '(S)he did not come.' (el.) }
\end{array}
$$

Section 6.1 is dedicated to the rich tonal morphology of the verbs used in various TAMP constructions; Section 6.2 explains the general patterns of the use of auxiliaries; Section 6.3 explores the expression of negation; and Section 6.4 presents the polysemy of prospective markers. A full description of the semantics of TAMP in Mano is provided by Khachaturyan $(2011,2015)$.

\subsection{Verbal forms used in TAMP constructions}

Mano verbs have rich suprasegmental morphology. The verbal morphology includes five grammatical tonal forms as well as four affixes. Some of the affixes only occur in combination with a tonal form. The verbal paradigms used in various finite and non-finite constructions have a total of ten forms, including a baer form with lexical tone and no segmental affixes; and three forms in which the only morphological exponent is grammatical tone (the imperfective form, conjoint form, and nominalization form). In addition, Mano has two forms that have grammatical tone combined with a segmental morpheme (real protasis and 
counterfactual protasis forms, both with the suffix-â) and three forms in which the exponent is a segmental morpheme (gerund and counterfactual, both with the

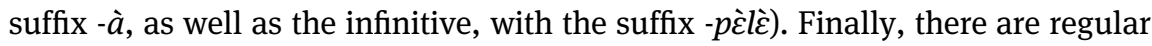
contractions of gerunds with the postposition $k a$ ' with'. No verbs contrast all forms; there is always at least some syncretism. Thus, conjoint forms are always homonymous with nominalization forms; gerunds are always homonymous with the counterfactual forms. Mid-tone CV verbs, such as $p \bar{a}$ 'fill', and high-tone CVCV verbs, such as félé 'become clear', have a maximum of seven contrasting forms, while the low-tone CVa verbs, such as nì̀ 'turn', contrast only three forms. Table 4 provides example paradigms.

\subsection{Auxiliaries}

The auxiliaries in Mande languages play an indispensable role in the expression of TAMP. A typologically remarkable feature of the TAMP system in Mano as well as in other Southern Mande languages and Southwestern Mande languages, is the rich inventory of auxiliaries. These not only contribute to the semantics of a particular TAMP construction, but they index the person and number of a subject. As in many other Mande languages, the Mano verb occurs in its lexical form and the auxiliary is the only exponent of the TAMP values in most TAMP constructions. Thus, TAMP constructions in $(36 \mathrm{a}-\mathrm{c})$ differ only in their marking of the auxiliary: the auxiliary of the past (36a), perfect (36b), and conjunctive series (36c).
a. $\overline{\boldsymbol{e}}$
nū.
3SG.PST come
'He came' (el.)
b. āà nū.
3SG.PRF come
'He has come' (el.)
$\begin{array}{llllllll}\text { c. } & m \bar{\imath} & \text { séñ } & \text { dàa } & \text { dj̀a } & \text { lê } & \text { é } & \text { nū! } \\ & \text { person } & \text { all } & \text { father } & \text { duty } & \text { COP } & \text { 3sG.CoNJ } & \text { come }\end{array}$
'Every person's father has to come (lit.: Every person's father's duty is he come).' (el.)

Other than expressing TAMP, Mano auxiliaries also index the person and number of a subject. In (36a), the form $\bar{e}$ not only expresses the past tense but also the subject's person (third) and number (singular). The auxiliary co-occurs with the full noun phrase of the subject. Instead of treating forms such as $\bar{e}$ as subject pronouns inflected for TAMP, an argument has been made to analyze them as TAMP markers (or auxiliaries) that are inflected for person and number and agree 


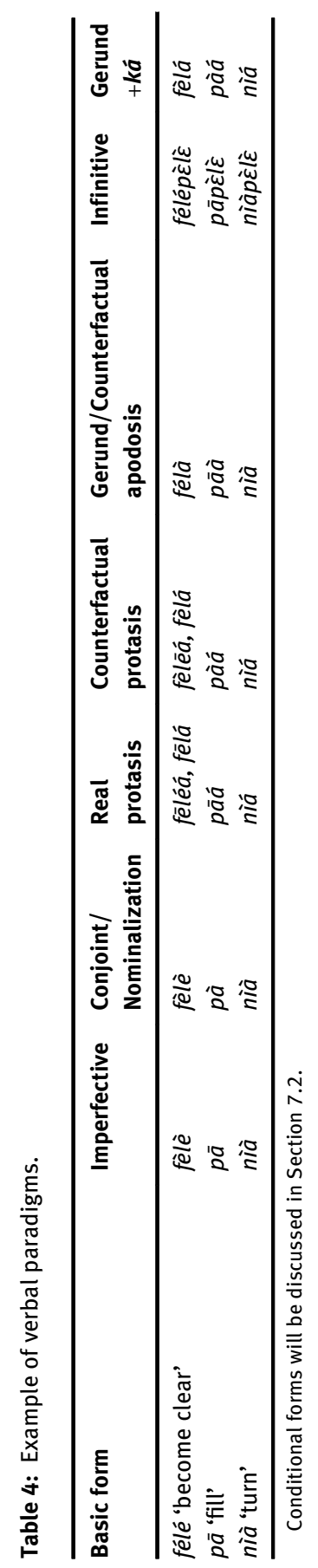


with the subject (Hachaturyan 2010). On (subject) agreement in Mande, see Konoshenko (2013; 2015). For more examples of subject indexing in the auxiliaries of African languages and more generally, for a discussion on the criteria used to distinguish free subject pronouns and bound pronominal markers, see Creissels (2005: 51-54). The full paradigm of Mano auxiliaries is given in Table A2 of the appendix.

\subsection{Negation}

Mano negation is expressed in copulas, auxiliaries and in additional predicative markers that are used in certain negative constructions.

Negation in Mano is asymmetric (in the sense proposed by Miestamo 2005). There are two reasons for this: negation involves a change in the TAMP constructions (constructional asymmetry) and the inventory of negative constructions is reduced with respect to the inventory of affirmative constructions (paradigmatic asymmetry). In particular, in negative non-verbal constructions, Mano only has one copula, wó, while affirmative non-verbal clauses contain either an existential

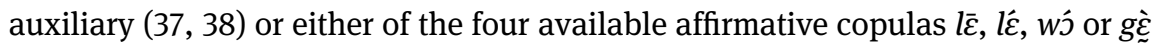
(39, 40). While Mano has three affirmative presentative constructions (40), no negative correlate occurs.
a. gó $w \bar{\varepsilon} \quad l \bar{\varepsilon}$
$\bar{\eta} \quad d \bar{\varepsilon}$
ká.
man:H DEM 3SG.EXI 1SG husband with
'This man is my husband.' (el.)
b. gó $w \bar{\varepsilon}$ wó $\bar{\eta} \quad d \bar{\varepsilon} \quad k a ́$.
man:H DEM COP.NEG 1SG husband with
'This man is not my husband.' (el.)

(38)
elephant PL 3PL.EXI EXI
'Elephants exist.' (el.)
a. bīe vj̀ $\overline{\boldsymbol{o}} \quad 6 \bar{e}$.
b. bīe vò wó $\quad \bar{e}$.
elephant PL COP.NEG EXI
'Elephants do not exist.' (el.)
(39) $\begin{array}{llll}\text { a. } & \grave{a} & 6 \bar{\jmath}-\grave{\jmath} & \mathbf{\varepsilon} .\end{array}$
3SG leave-GER COP
'He has left (lit.: his leaving is).' (el.)
b. $\begin{aligned} & a \\ & a\end{aligned} \bar{j}-\grave{j}$ wáâ
3SG leave-GER COP.NEG>3SG with
'He has not left (lit.: his leaving isn't it).' (el.)




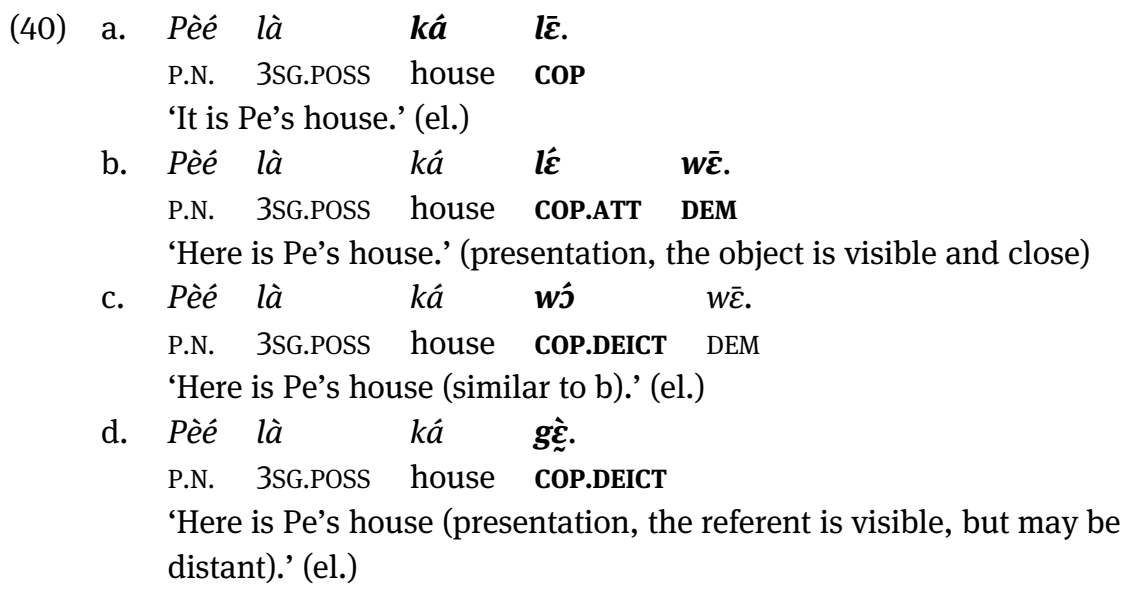

In declaratives, only one negative auxiliary combines with different lexical and grammatical means, and that auxiliary is used to form negative habitual, aorist, and perfect constructions, whereas in the affirmative zone, three different auxiliaries are used for these purposes (41). The inventory of affirmative modal constructions does not map into the inventory of negative ones: thus, there is no direct negative equivalent of the prospective construction (see Section 6.4).
a. $\quad l \hat{\varepsilon} \dot{\varepsilon}$
$l \bar{o}$
losó
vs
b. ľ̀́
ló losjí.
3SG.IPFV go:IPFV market
3SG.NEG go market
'She goes to the market.' (el.) 'She does not go to the market.' (el.)

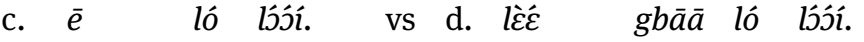
3SG.PST go market 3SG.NEG NEG go market
'She went to the market.' (el.) 'She did not go to the market' (el.)

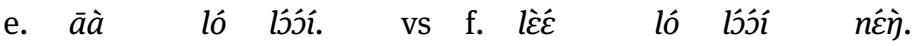
3SG.PRF go market 3SG.NEG go market yet
'She has gone to the market.' (el.) 'She has not yet gone to the market.' (el.)

In addition to auxiliaries that have negative polarity (the negative series, as illustrated in (41), but also prohibitive) and the negative copula wó, Mano employs negative predicative markers, including $g b \bar{a} \bar{a}$ (41d), which is used in negative perfective constructions. It is important to note that another negative predicative marker, gòa a , is used only in negative conditional constructions. Conditional clauses in Mano use extensive dedicated morphology, see Section 7.2. 


\subsection{Prospective}

In contrast to other auxiliary series, the prospective series is always used with another auxiliary: it most often appears with the conjunctive auxiliary (with which it regularly merges). The series also stands out phonotactically because the markers have the form CVCV or CVCVCV, which is not attested elsewhere in the auxiliary paradigm. The series also has a peculiar polysemy. First, the series is used in quotative constructions (42); second, when the prospective auxiliary is combined with a conjunctive auxiliary coreferential with it, the entire construction conveys the modality of intentionality $(43,44)$ and prospective aspectual value, whereas a future action or state is expected to occur given the present state of affairs $(45,46)$.

In the quotative construction, the prospective marker is the sole means of introducing reported speech; there is no speech verb. The marker may optionally be followed by a conjunction kélè. The quoted predication can take any form; in (42), it is represented by a copula construction.

\begin{tabular}{|c|c|c|c|}
\hline $\begin{array}{l}\text { yèlè } \\
\text { 3SG.PROS } \\
\text { ‘He says }\end{array}$ & $\begin{array}{l}\text { àmj́j̀ywò gbàlà } \\
\text { therefore Kpelle } \\
\text { his is why there are } \\
\text { fore the Kpelle peo }\end{array}$ & $\begin{array}{l}\text { mià } \\
\text { person.PL }\end{array}$ & $\begin{array}{lll}y \grave{a}-\grave{a} & l \bar{\varepsilon} & l \\
\text { sit-GER } & \text { COP } & \end{array}$ \\
\hline wūlū & $g b \bar{a} \bar{a}$ & é & kpíli \\
\hline vulu & 3SG.PROSP now & 3SG.CONJ & celebration \\
\hline
\end{tabular}

\begin{tabular}{|c|c|c|c|c|}
\hline gwś & $t \hat{\varepsilon}$ & mòlj̀ & $\dot{\eta}$ & gè $\bar{e}$ \\
\hline problem & ATT & 1SG.PROSP & $1 \mathrm{SG} . \mathrm{CONJ}>3 \mathrm{SG}$ & say \\
\hline
\end{tabular}

\begin{tabular}{|c|c|c|c|c|c|c|c|}
\hline áà & nù & mais & $\grave{a}$ & $z \grave{\imath}$ & $n \bar{u}$ & kj̀ & $w \bar{\varepsilon}$ \\
\hline 3SG.JNT & come:JNT & but[FR] & $3 S G$ & INT.POSS & come & way:CSTR & DEM \\
\hline & lèpèlé & yèlé & & & $d \bar{\jmath}$. & & \\
\hline 3SG.EXI & like & 3SG.PRO & $\mathrm{SP}>3 \mathrm{SS}$ & G.CONJ & stop & & \\
\hline
\end{tabular}

'He was approaching but the way he was approaching was like he was going to stop.' (nat.)

$\begin{array}{lllll}\text { yèlè } & g b \bar{a} \bar{a} & \dot{e} & \text { pélésínè } & \text { dùò. } \\ \text { 3SG.PROSP } & \text { now } & \text { 3SG.CONJ } & \text { penicillin } & \text { throw } \\ \text { 'She was about to inject penicillin.' (nat.) }\end{array}$

Quotative indexes are not uncommon in Mande. They are particularly widespread in Manding (on quotative indexes in Mandinka, see Creissels \& 
Sambou 2013: 441-443). In some Mande languages, quotative indexes can be inflected for person and number (Idiatov 2010). Syntactically, in Mano, as in Mandinka or in Tura, another Southern Mande language, quotative indexes are used as quotative predicators, which are defined as a predicative element "similar to quotative verbs that cannot be classified as full-fledged verbs in a given language" (Güldemann 2008b: 15). Idiatov (2010) reported on other Mande languages with quotative indexes, in particular, Jula of Samatiguila or the Ko dialect of Mende (Western Mande) and observed that they are used non-predicatively as clauselinking markers. A polysemy such as the one attested in Mano (quotative, intentionality) has also been attested in Wan, Southern Mande (Nikitina 2018a), while Mandinka adds prospective to the range of meaning that is expressed by the quotative construction (Creissels and Sambou 2013: 443-445). The same type of polysemy is also widely attested outside the Mande family. On the development of intentionality meanings from quotatives, see Güldemann (2008b); on the development of future-related verbal meanings out of intentionality, see Bybee et al. (1994). Given the cross-linguistic tendencies in grammaticalization (quotative > intention > prospective), the Mano prospective series most likely emerged from a fusion of pronominal elements with some quotative index or a verb. However, the identity of that index or that verb and in general the origin of the series remain unresolved questions.

\section{The morphosyntax of complex clauses}

To combine clauses, Mano often employs dedicated TAM categories and constructions. More specifically, for a series of consecutive or simultaneous events, Mano uses the conjoint construction (Section 7.1). Conditional clauses are cross-linguistically unusual because they employ extensive specialized verbal morphology, but also because their semantics are far from the prototype described in the literature (see Section 7.2). Other morphological means used for clause-combining are linkers, determiners, conjunctions, and clause-final markers. Linkers are used for coordi-

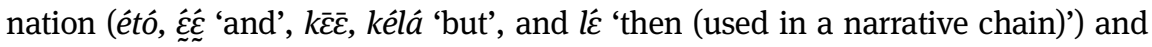
subordination ( $y e$ 'when', $k \bar{\varepsilon}$ 'so that (purpose constructions)', $b \bar{\imath}$ 'because'). Linkers typically occur at the beginning of a phrase and may occur after a pause. Determiners, and especially $l \hat{\varepsilon}$, nć, $t \hat{\varepsilon}$, high-tone floating marker are used in relative clauses following a relativized constituent. Conjunctions, and most prominently kélè, are used in complement clauses and reported speech, usually form a prosodic unit with a preceding clause, and occur before a pause. Finally, clause final 
backgrounding markers occur at the right edge of a sentence-initial dependent clause and are sometimes used as the only clause-linking devices. ${ }^{11}$

\subsection{Conjoint form}

The conjoined construction in Mano, which consists of an auxiliary of the conjoint series and a verb in the low-tone conjoined form, is an example of a clausechaining category that occurs commonly in languages of Sub-Saharan Africa, where in a chain of clauses representing a sequence of events, only one is finite and the remaining clauses exhibit some properties of non-finiteness. ${ }^{12}$ The Mano construction is primarily used in the narrative chain. The narrative is usually divided into micro-episodes, with the first event in the perfective, and the subsequent events in the conjoint construction, and the subjects of the respective constructions are typically (but not always) coreferential.

$\bar{e} \quad l \grave{a} \quad p \bar{j}$ sí
3SG.PST 3SG.POSS thing.PL pick.up direcly

Speech verbs in narratives more often than other verbs occur in the conjoint form. Furthermore, switching reference of the subject is a norm, rather than an

11 All the particularities of the syntax of complex clauses in Mano and Mande in general are beyond the scope of the present paper. More specifically, I do not include a discussion of the relative clauses that belong to the correlative type and have a typologically unusual clauseinternal subtype (Nikitina 2012). In Khachaturyan (2017b), I analyze Mano relative clauses as a pragmatic interpretation of a paratactic construction with a pragmatically backgrounded dependent clause, similar to a topic-comment construction (Van Valin 2005; see also Lambrecht 1994). An analysis of correlatives as being non-embedding or as straightforwardly topicalized has been proposed in Mande for Maninka of Kita, Manding, in the former case (Creissels 2009) and in Wan, Kla-Dan and other Southern Mande, in the latter (Makeeva 2013; Nikitina 2012).

12 This type of forms with reduced finiteness are also referred to as consecutive (see Carlson 1994 for Supyire, Atlantic) or sequential (see Frajzyngier 1996; Hellwig 2011 for Chadic). The term "conjoint" is selected for Mano for semantic reasons, because the marking in question is used not only to represent a sequence of events but also simultaneous events, and also because of the particularities in the syntactic behavior: conjoint constructions can be used in independent clauses. The term "conjoint" is also used in African linguistics - particularly in the studies of Bantu languages - to designate a morphological opposition between conjoint and disjoint, the forms of which have a different functional load than the "conjoint" forms in Mano, see van der Wal and Hyman (2016). 
exception. Example (48) represents a reported dialog, so in (48b) and (48c), the subject of the speech verb is different from each immediately preceding one.
a. láà
gèē: $\quad$ wáá
pè̀̀l $n \bar{\jmath}$.
3SG.IPFV >3SG say:IPFV thousand two give
'He says: give 2000 (francs).'
b. âà
gèè:
wáá
pèèlē wó
$\bar{\eta} \quad k \dot{\varepsilon} l \grave{\varepsilon}$.

3SG.JNT>3SG say:JNT thousand two COP.NEG 1SG hand

'He says: I don't have 2000.'

$\begin{array}{llllllll}\text { c. áà } & \text { gèè } & \text { gj̃ } & \text { wélé } & 6 j \bar{j} & n \bar{\jmath} & m \bar{\jmath} j . \\ & \text { 3G.JNT>3SG } & \text { say:JNT } & \text { cola } & \text { bone } & \text { simple } & \text { give } & \text { PART }\end{array}$

'He says: give me at least two cola nuts.'

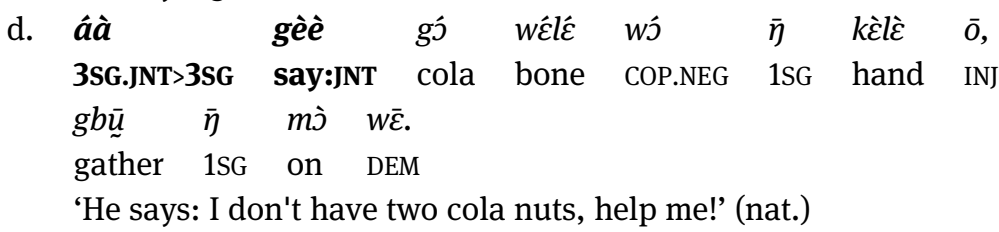

The chain of conjoined constructions is rarely very long, consisting of a maximum of three to four clauses. A good balance between perfective and conjoined constructions creates a stylistic effect of narrative fluidity, and is a sign of a good narrator. However, children typically overuse perfective constructions because often they have not yet fully acquired the art of storytelling. The use of the conjoint construction in the Mano narrative remains an object for future study (for an analysis of aspectual marking used for narrative structuring in Totela, a Bantu language, see Crane 2011).

The conjoint construction is also used to express events that occur simultaneously with some other event:

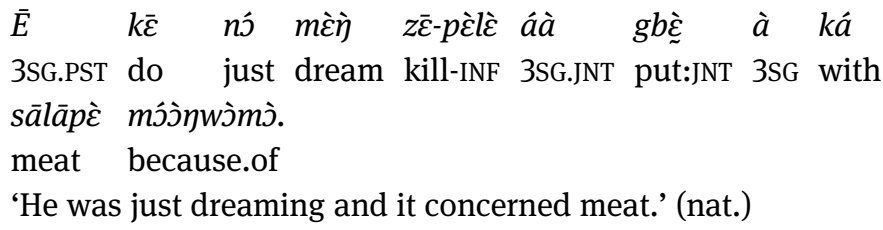

It is important to note that while the conjoint construction in the narrative is usually used as part of a chain of statements, during conversation, it alone can constitute a turn and even occur in a question. This type of conjoint construction occurred in an example suggested by my language consultant, when a question that contained a conjoint construction was asked by one participant in a conversation (50c) as a direct follow-up of a prior question framed in a regular non-verbal predication (50a). 


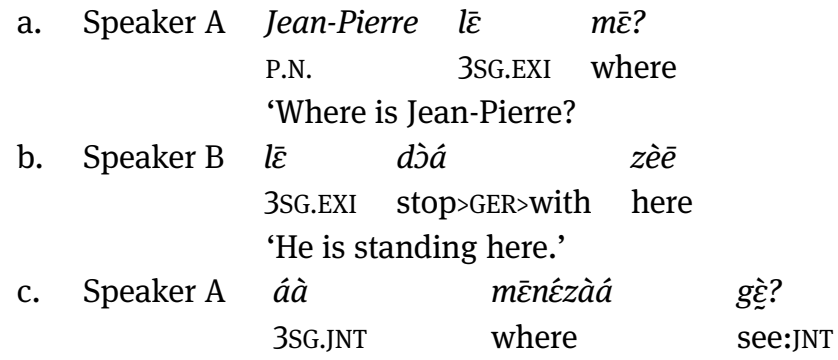

'what is he looking at? (Why doesn't he see I am calling him?)' (el.)

Thus, while the conjoint construction does not need to immediately follow a clause expressed by a full-fledged aspectual construction (perfective, in the case of a sequence of actions in the narrative, or some other construction, in the case of simultaneous events), it is always directly or indirectly related to some situational landmark. For an analysis of a similar construction, "null tense", in Wolof, Atlantic, employing the notion of discursive anchor point, see Robert (2010). Givón (2001: 357) classified clause-chaining with the help of forms with reduced finiteness into two types: clause-chaining in which the finite-most predication is the ultimate member of a chain, which corresponds to the SOV word order, and clausechaining in which the finite-most predication is the first member of a chain, and this corresponds to the VO word order. As observed by Creissels (2018: 804), Mande languages, as exemplified by Mano, put the finite-most clause in the initial position of the chain and challenge this typology by not being VO but rather OV languages, or to be more precise, SOVX languages. Therefore, as Creissels concludes, the relevant parameter in the typology of clause-chaining should not be OV versus VO, but rather verb-final versus verb-medial.

\subsection{Conditionals}

Mano conditional clauses deserve typological attention due to the richness of dedicated conditional morphology and owing to semantic patterns that do not conform to typological prototypes. First, while Mano verbal paradigms have ten morphological distinctions, three of them are employed solely in conditional clauses, including two dedicated tonal forms, conditional and irrealis, combined with the conditional suffix $-\hat{a}$ and a counterfactual form with the suffix $-\grave{a}$. The contrasts in verbal forms are illustrated by the verb ló 'go': lō-á go:COND-COND vs lò-á go:IRREALCOND vs ló-à go-CNTRFCT. In addition, as noted in Section 6.3, of the two negative predicative markers, one, gơ à gj̃ , appears only in conditional constructions. 


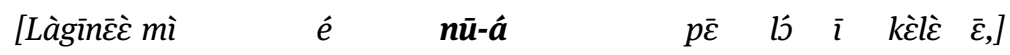
Guinea person:CSTR 3SG.CONJ come:COND-COND thing buy 2SG hand BKGR $\begin{array}{lllllll}y e ́ k \grave{\varepsilon} & e & \bar{e} & k j & p a ́ & a & m j\end{array}$ better.not.to 3SG.CONJ 3SG.REFL arm touch 3SG on 'If a Guinean person wants to buy something from you, he'd better not touch it.' (nat.)
[kó lō-á
bèi
zàá] kóò lo
$l \bar{l} \quad \bar{a} \quad g \grave{\varepsilon}-\bar{\varepsilon}$.
1PL.CONJ go:COND-COND downstream in 1PL.IPFV go:IPFV 3SG see-GER 'If we go downstream, we will see it.' (nat.)

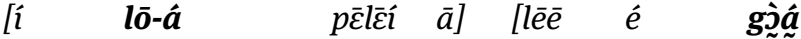

2SG.CONJ go:COND-COND village BKGR woman 3SG.CONJ NEG.COND

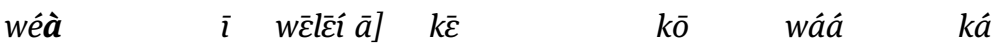

speak.CNTRFCT 2SG face BKGR at.that.moment 1PL.EMPH COP.NEG>3SG with $k \bar{\varepsilon} \quad k o ́ \quad l i \quad y \bar{e}$.

that 1PL.CONJ 2SG.EXI give.birth

'If you go to the village and no woman speaks to you, then we are not those who gave birth to you.' (nat.)
[è
$\boldsymbol{k} \grave{\varepsilon}-\hat{a}$
$w \bar{a}$
$d \bar{\jmath} \quad \bar{\jmath}]$
òo
gう̀

3SG.SBJV do:IRREAL-COND 3PL.PST>3SG knOW BKGR 3PL.NEG NEG.COND

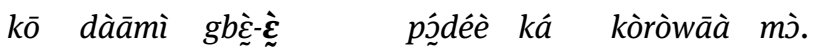
1PL master put-CNTRFCT nail with cross on 'If it had been (so that) they knew him, they would not have put him with nails on the cross.' (nat.)

On the semantic side, Mano makes a formal distinction between real (51), imaginative (52), and predictive conditionals (53), on the one hand, and counterfactual conditionals (54), on the other. In the former, the protasis is formed by a conjunctive auxiliary with the conditional verbal form (élóa 'if he goes'), and in the latter, the protasis is formed with a subjunctive auxiliary and an irrealis verbal form (è lòa 'if (s)he had gone') (on the semantic classification of conditionals, see Thompson et al. 1997). The repartition of conditional types in these two categories, counterfactual and non-counterfactual, does not correspond to a prototypical realis/irrealis distinction with real situations coded differently from hypothetical and counterfactual situations. Thus, in Nanti, Arawak, real conditionals contain realis marking and are therefore different from all other types of conditionals containing irrealis (such as in hypothetical conditionals) or double irrealis marking (as in counterfactuals; see Michael 2014). While marking counterfactual conditionals as a distinct type is not uncommon across languages (Lazard 1998 mentions a 
few), these cases often contain the same marker for the protasis and apodosis of counterfactual conditionals. For example, this occurs in Rembarrnga, non-PamaNyungan (Verstraete 2005) or in Hausa, Chadic (Bagari 1976). In contrast, in Mano, protasis and apodosis in conditionals, including counterfactuals, are expressed by strikingly different constructions. Yet in Mano, the distinction between counterfactual and non-counterfactual conditionals is far from fixed, because a noncounterfactual construction can be used in a semantically counterfactual context, as in (55) (no examples of the reverse type have been attested), which contributes to blurring the distinction between realis and irrealis. For a critique of the crosslinguistic validity of the notion of irrealis, see Bybee (1998) and Cristofaro (2012).

\begin{tabular}{|c|c|c|c|c|}
\hline$[\hat{i}$ & $n \bar{u}-\hat{a}$ & $\bar{a}]$ & $m \bar{i} \bar{a}$ & óò \\
\hline 2SG.CONJ & come:COND-COND & BKGR & person.PL & 3PL.IPFV \\
\hline $1-$ & $g b \underline{\sim} \bar{u}-\underline{u}$ & $\bar{\imath}$ & mj̀. & \\
\hline o:IPFV & gather-GER & $2 \mathrm{SG}$ & on & \\
\hline
\end{tabular}

'(Given that you had nothing,) if you had come, the people would have helped you (if you come, people will help you).' (nat.)

The existence of dedicated conditional morphology notwithstanding, no sharp boundary occurs between the conditional and other types of constructions. This means that non-counterfactual apodosis in Mano is always expressed by a nondedicated construction $(52,53)$. Mano is similar to some Papuan languages (Thompson et al. 1997) in that it lacks a clear distinction between "if" and "when" clauses. Thus, on the one hand, temporal constructions may receive a conditional interpretation, as in (56), with the negative counterfactual protasis expressed by a negative copular construction with the linker yé 'when' which is typically used in temporal clauses. The value of counterfactuality in (56) is expressed by the marker of a retrospective shift, $k \grave{\varepsilon} i$. On the other hand, formally conditional constructions often receive a temporal, non-conditional interpretation, as in (57).

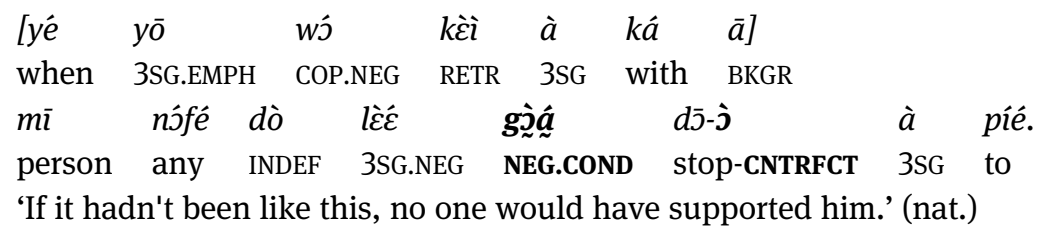

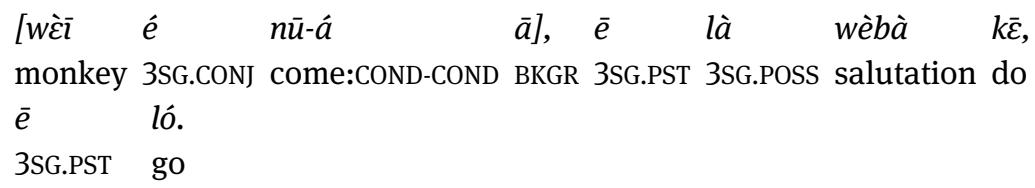

'When the monkey came, it did its greeting and went away.' (nat.) 


\section{Conclusion}

The present article sketches a linguistic portrait of Mano as a representative member of the Mande family and its Southern branch. I hope that it attracts the attention of typologists to the family. The family features shared by Mano include S-Aux-O-V-X word order, the parallelism between nominal and verbal syntax, the possessive split, the expression of TAMP at the level of the auxiliary in addition to, or often instead of, verbal morphology, the ubiquity of passive lability, and the narrative structuring of clausal sequences in which the most finite clause is the first in the chain. The Southern branch features include rich tonal morphology, the unstable character of nasal consonants, and rich pronominal paradigms, including auxiliaries that index the person and number of the subject. Some of the features presented here have not been sufficiently analyzed in the Mande material, so it is unclear whether Mano is unusual in comparison to other Mande languages in terms of large class of inalienably possessed nouns, or the clause-level nominalization, which may include another clause as its constituent. Finally, some properties are almost certainly specific to Mano, such as the dedicated tonal forms used in conditional clauses.

Acknowledgments: This paper is a result of more than ten years of work with the Mano-speaking communities, and I am very grateful to the Mano people for all they have taught me, and all the time we have spent together. I am particularly indebted to my primary language consultants and their families for their help, care and patience: Pe Mamy, Cé Simmy, Émile Loua and Elie Sandy. I thank Maria Koptjevskaja-Tamm and Denis Creissels for their generous comments on different versions of the manuscript. Both anonymous reviewers and the proofreader of the paper, Kate Moore helped improve the manuscript. Last but not the least, I would like to thank Valentin Vydrin for taking me on this Mande adventure and for inspiring me throughout my student years and even afterward 


\section{Appendix}

Table A1: Mano personal pronouns.

\begin{tabular}{|c|c|c|c|c|c|c|}
\hline & 1SG & $2 \mathrm{sG}$ & $3 s \mathrm{sg}$ & 1PL & $2 \mathrm{PL}$ & 3PL \\
\hline non-subject pronouns & $\bar{\eta}$ & $\bar{i}$ & $\grave{a} / \bar{a} / a^{13}$ & $k \bar{o}$ & $k \bar{a}$ & $\bar{o}$ \\
\hline possessive pronouns & $\grave{\eta}$ & bà & là & kò & kà & wà \\
\hline emphatic pronouns & $m \bar{a}(\bar{e})$ & $\operatorname{bi}(\bar{e})$ & $\grave{a},(\grave{a}) y \bar{e}, y \bar{o}$ & $k \bar{o}(\bar{e})$ & $k \bar{a}(\bar{e})$ & $\bar{o}(\bar{e})$ \\
\hline focalized pronouns & $m a ́$ & bí & (à) yé & kó & ká & $o ́$ \\
\hline inclusory pronouns & & & & 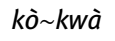 & kà & wà \\
\hline
\end{tabular}

The marker in parentheses is a portmanteau marker. It represents an auxiliary fused with the non-subject pronoun of the third person singular which can occupy the position of the direct object (in this case, the portmanteau auxiliary will represent the result of the fusion with the direct object), as well as in the position of the possessor of inalienably possessed noun. If in a given cell there is no marker in parentheses (for example, in the series of the perfect, III, and in the conjoint series, V), it means that the marker in the cell can be used in both transitive and intransitive contexts without the pronominalized direct object of the third person singular being explicitly marked.

\section{Abbreviations (not included Leipzig Glossing Rules):}

ADR - addressee, ATT - attention management, CNTRFCT - counterfactual, CONJ conjunctive, CSTRformDEICT - deictic, EXI - existential, GER - gerund, $\mathrm{H}$ - high tone, INJ - interjection, INT - intensifier or intensity, IP - inclusory pronoun, IRREAL irrealis, JNT - conjoint, PART - particle, P.N. - proper noun, PROSP - prospective, RED reduplication, REF - referential status, RETR - retrospective, SBJV- subjunctive.

\section{ISO 639-3 codes of languages cited:}

Mande languages: Bamana (bam), Beng (nhb), Dan (daf), Guinean Kpelle (gkp), Guro (goa), Jalonke (yal), Jula (dyu), Kakabe (kke), Kassonke (kao), Liberian Kpelle (xpe), Mandinka (mnk), Maninka of Kita (mwk), Mano (mev), Mende (men), Mwan (moa), Soninke (snk), Toura (neb), Wan (wan). Other languages: Akan (aka), Baoulé (bci), Belhare (byw), French (fra), Halkomelem (hur), Hausa (hau), Hindi

13 The tone of the 3sg non-subject pronoun optionally assimilates to the tone of the preceding vowel. 


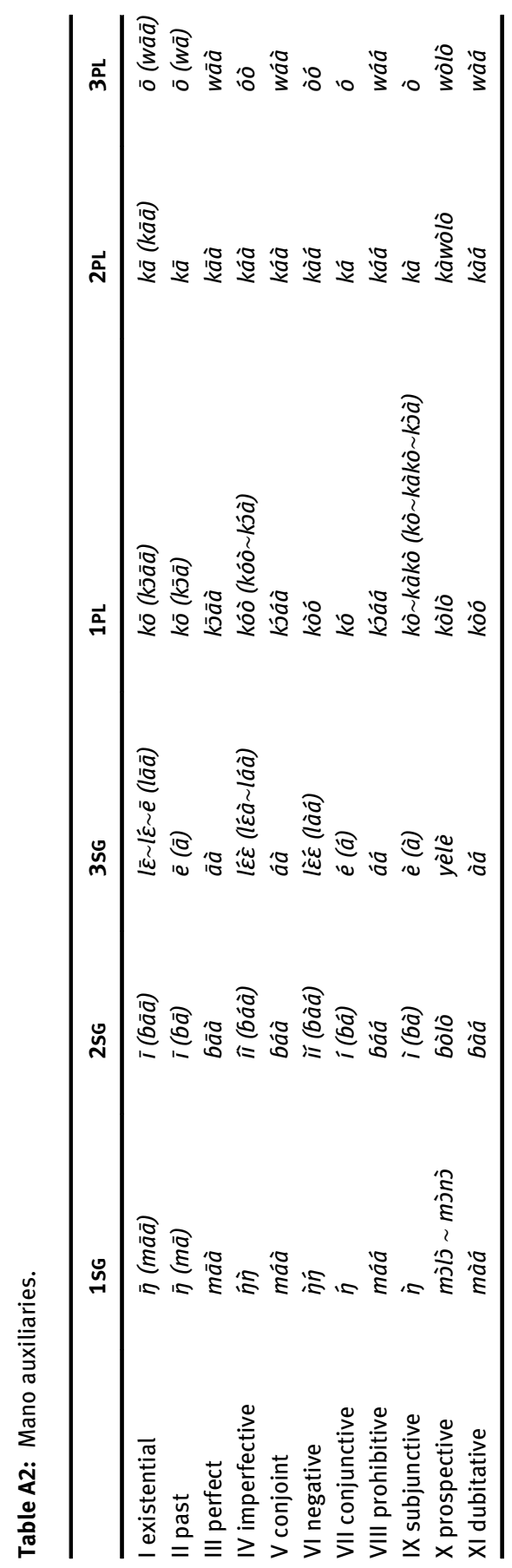


(hin), Hittite (hit), Hungarian (hun), Kashaya (kju), Lavukaleve (lvk), Mon (mnw), Nanti (cox), Ossetic (os), Polish (pol), Rembarrnga (rmb), Russian (rus), Tariana (tae), Tolai (ksd), Totela (ttl), Turkish (tur), Wolof (wol).

\section{References}

Aikhenvald, Alexandra Y. 2003. A grammar of Tariana, from Northwest Amazonia. Cambridge: Cambridge University Press. https://doi.org/10.1017/СB09781107050952.

Aplonova, Ekaterina \& Valentin Vydrin. 2017. Гоо язык [The Goo language]. In Valentin Vydrin, Yulia Mazurova, Andrej Kibrik \& Elena Markus (eds.), Языки мира: Языки манде [Languages of the world: Mande languages]. 457-469. St. Petersburg: Nestor-Historia.

Bagari, Dauda Muhammad. 1976. Subordinate adverbial clauses in Hausa. PhD dissertation. Los Angeles: University of California.

Bril, Isabelle. 2004. Coordination strategies and inclusory constructions in New Caledonian and other Oceanic languages. In Martin Haspelmath (ed.), Coordinating constructions (Typological studies in language 58), 499-536. Amsterdam: John Benjamins.

Bybee, Joan. 1998. “Irrealis" as a grammatical category. Anthropological Linguistics 40. 257-271. Bybee, Joan, Revere Perkins \& William Pagliuca. 1994. The evolution of grammar: Tense, aspect, and modality in the languages of the world. Chicago: Chicago University Press.

Carlson, Robert. 1994. A grammar of Supyire (Mouton grammar library 14). Berlin: De Gruyter Mouton. https://doi.org/10.1515/9783110883053.

Cobbinah, Alexander \& Friederike, Lüpke. 2009. Not cut to fit - zero-coded passives in African languages. In: Matthias Brenzinger \& Fehn, Anne-Maria (Eds.), Proceedings of the 6th WOCAL World Congress of African Linguistics, Cologne, 17-21 August 2009. Cologne: Rüdiger Köppe, 153-165.

Corbett, Greville G. 2000. Number. Cambridge: Cambridge University Press.

Corbett, Greville G. 2009. Suppletion: Typology, markedness, complexity. In Patrick 0. Steinkrüger \& Manfred Krifka (eds.), On inflection (Trends in linguistics studies and monographs 184), 25-40. Berlin: Mouton de Gruyter.

Crane, Thera Marie. 2011. Beyond time: Temporal and extra-temporal functions oftense and aspect marking in Totela, a Bantu language of Zambia. PhD dissertation. Berkeley: University of California.

Creissels, Denis. 1994. Aperçu sur les structures phonologiques des langues négro-africaines. Grenoble: ELLUG.

Creissels, Denis. 2005. A typology of subject and object markers in African languages. In F. K. Erhard Voelz (ed.), Studies in African linguistic typology (Typological studies in language 64), 43-70. Amsterdam: John Benjamins.

Creissels, Denis. 2009. Les relatives corrélatives: le cas du malinké de Kita. Langages 174 (2), 39-52.

Creissels, Denis. 2014. P-lability and radical P-alignment. Linguistics 52 (4), 911-944.

Creissels, Denis. 2016. Phonologie segmentale et tonale du soninké (parler du Kingi). Mandenkan 55, 3-174.

Creissels, Denis. 2017. Construct forms of nouns in typological perspective. Paper presented at the Societas Linguistica Europaea-50. 
Creissels, Denis. 2018. Current issues in African morphosyntactic typology. In Tom Güldemann (ed.), The languages and linguistics of Africa (The world of linguistics 11), 712-821. Berlin: De Gruyter Mouton.

Creissels, Denis \& Nguessan Kouadio. 1977. Description phonologique et grammaticale d'un parler baoulé. Abidjan: Institut de Linguistique Appliquée.

Creissels, Denis \& Pierre Sambou. 2013. Le mandinka. Phonologie, grammaire, textes. Paris: Karthala.

Cristofaro, Sonia, 2012. Descriptive notions vs. grammatical categories: Unrealized states of affairs and 'irrealis'. Language Sciences 34, 131-146.

Dahl, Östen \& Maria Koptjevskaja-Tamm. 1998. Alienability splits and the grammaticalization of possessive constructions. In XVIth Scandinavian conference of linguistics, 38-49: University of Turku \& Åbo Akademi.

Dahl, Östen \& Maria Koptjevskaja-Tamm. 2001. Kinship in grammar. In Irene Baron, Michael Herslund \& Finn Sørensen (eds.), Dimensions of possession (Typological studies in language 37), 202-225. Amsterdam: John Benjamins.

Daniel, Mikhail. 2000. Типология ассочиатиной множественности [A typology of associative plurality]. PhD dissertation: Moscow State University.

Dimmendaal, Gerrit \& Anne Storch. 2016. Niger-Congo: A brief state of the art. Oxford handbooks online in linguistics. Oxford: Oxford University Press.

Dressler, Wolfgang. 1985. Suppletion in Word-Formation. In Jacek Fisiak (ed.), Historical semantics. Historical word formation (Trends in linguistics. Studies and monographs 29), 97-112. Berlin: Mouton.

Foley, William A.2014. A comparative look at nominalizations in Austronesian. In I Wayan Arka \& Ni Luh KetutMas Indrawati (eds.), Argument realisations and related constructions in Austronesian languages: Papers from 12-ICAL (Asia-Pacific Linguistics 13), vol. 2, 1-51. Canberra: Asia-Pacific Linguistics.

Frajzyngier, Zygmunt. 1996. Grammaticalization of the complex sentence: A case study in Chadic. Studies in language companion series 32. John Benjamins, Amsterdam.

Gildea, Spike. 1998. On reconstructing grammar: Comparative Cariban morphosyntax. Oxford: Oxford University Press.

Givón, Talmy. 2001. Syntax. Volume II. Amsterdam: John Benjamins.

Green, Christopher, 2018. A survey of word-level replacive tonal patterns in Western Mande. Mandenkan 59, 67-108.

Güldemann, Tom. 2008a. The Macro-Sudan belt: Towards identifying a linguistic area in northern sub-Saharan Africa. In Bernd Heine \& Derek Nurse (eds.), A linguistic geography of Africa, 151-185. Cambridge: Cambridge University Press.

Güldemann, Tom. 2008b. Quotative indexes in African languages. A synchronic and diachronic survey. Berlin: Mouton de Gruyter.

Hachaturyan, Maria. 2010. The syntactic approach to pronominal systems in South and SouthWestern Mande languages. In Abstracts and papers of the international workshop on personal pronouns in Niger-Congo languages, 42-47. St. Petersburg, 13-15 September 2010.

Haspelmath, Martin. 1993. More on the typology of inchoative/causative verb alternations. In Bernard Comrie \& Maria Polinsky (eds.), Causatives and transitivity (Studies in language companion Series 23), 87-120. Amsterdam: John Benjamins.

Haspelmath, Martin (Ed.), 2004. Coordinating constructions (Typological studies in language 58). John Benjamins, Amsterdam.

Hellwig, Birgit. 2011. A grammar of Goemai. Berlin, Boston: De Gruyter Mouton. 
Hyman, Larry M., 2009. How (not) to do phonological typology: The case of pitch-accent. Language Sciences 31, 213-238.

Hyman, Larry M., 2011. Does Gokana really have no syllables? Or: what's so great about being universal?. Phonology 28 (1), 55-85.

Hyman, Larry M., Hannah Sande, Florian Lionnet, Nicholas Rolle \& Emily Clem. 2018. Prosodic systems: Niger-Congo and adjacent areas. In Carlos Gussenhoven \& Aoju Chen (eds.), Oxford Handbook of Language Prosody. https://hsande.georgetown.domains/documents/ ProsodicSystems.pdf.

Idiatov, Dmitri. 2010. Person-number agreement on clause linking markers in Mande. Studies in Language 34 (4), 832-868.

Idiatov, Dmitry \& Ekaterina Aplonova. 2017. Тура язык [The Tura language]. In Valentin Vydrin, Yulia Mazurova, Andrej Kibrik \& Elena Markus (eds.), Языки мира: Языки манде [Languages of the world: Mande languages], 583-616. St. Petersburg: Nestor-Historia.

Khachaturyan, Maria. 2011. Le système prédicatif du mano de Guinée. Mandenkan 47. 13-55.

Khachaturyan, Maria. 2014. Grammaire de la langue mano (mandé-sud) dans une perspective typologique. PhD dissertation. Paris: Inalco.

Khachaturyan, Maria, 2015. Grammaire du mano. Mandenkan 54, 1-252.

Khachaturyan, Maria, 2017a. Bound noun plus verb combinations in Mano. Mandenkan 57, 3-24.

Khachaturyan, Maria. 2017b. Relative clauses as a result of cooptation: the case of Mano correlatives. Paper presented at the SLE-2017, Zürich.

Khachaturyan, Maria. 2018. A sketch of dialectal variation in Mano. Mandenkan 59, 31-56.

Khachaturyan, Maria. 2019. Inclusory pronouns in Mande: The emergence of a typological rarum. Folia Linguistica 53, 87-123.

Khachaturyan, Maria. 2020. From the Qur'an to Christianity: Ethnolinguistic contact and religious conversion in West Africa. Cahiers d'Études Africaines 239.

Konoshenko, Maria. 2013. Лично-числовое маркирование в языке кпелле: к типологии маркирования по лицу и числу [Person and number marking in Kpelle: towards a typology of person and number agreement]. Voprosy Jazykoznanija 1. 95-114.

Konoshenko, Maria. 2014. The syntax of tone in Guinean Kpelle. In Proceedings of the fortieth annual meeting of the Berkeley Linguistics Society, 233-252. Berkeley, CA.

Konoshenko, Maria. 2015. Лично-числовое согласование в языках манде: внутригенетическая типология. [Person and number agreement in Mande languages: $A$ family-internal typology.]. PhD dissertation. Moscow: Institute of Linguistics, Russian Academy of Sciences.

Konoshenko, Maria. 2017. Кпелле язык [The Kpelle language]. In Valentin Vydrin, Yulia Mazurova, Andrej Kibrik \& Elena Markus (eds.), Jazyki mira: Jazyki mande (Языки мира: Языки манде) [Languages of the world: Mande languages], 284-343. St. Petersburg: Nestor-Historia.

Konoshenko, Maria, 2018. Word-level replacive tonal patterns in Mande nominal constructions: On Christopher Green's binary typology. Mandenkan 59, 109-120.

Koptjevskaja-Tamm, Maria. 1993. Nominalizations. London/New York: Routledge.

Kuznetsova, Natalia. 2007. Le statut fonctionnel du pied phonologique en gouro. Mandenkan (43). 13-45.

Kuznetsova, Olga. 2011. Лабильность в языке гуро [Lability in the Guro language]. Acta Linguistica Petropolitana VII(2). 263-278.

Lambrecht, Knud. 1994. Information Structure and Sentence Form. Topic, Focus and the Mental Representation of Discourse Referents. Cambridge: Cambridge University Press. 
Lazard, Gilbert. 1998. L'expression de l'irréel: Essai de typologie. In Leonid Kulikov \& Heinz Vater (eds.), Typology of verbal categories: Papers presented to Vladimir P. Nedjalkov, 237-247. Tübingen: Niemeyer.

Lee, Amy Pei-jung. 2011. Comitative and coordinate constructions in Truku Seediq. Language and Linguistics 12(1). 49-75.

Lefebvre, Claire \& Pieter Muysken. 1987. Mixed categories. Nominalizations in Quechua. Dordrecht/Boston/London: Kluwer Academic Publishers.

Letuchij, Alexander.2013. Типология лабильных глаголов [A typology of labile verbs]. Moscow: Jazyki slav'anskikh kul'tur.

Lichtenberk, Frantisek, 2000. Inclusory pronominals. Oceanic Linguistics 39, 1-32.

Lüpke, Friederike, Storch, Anne, 2013. Repertoires and choices in African languages (Language contact and bilingualism 5). De Gruyter Mouton, Berlin.

Makeeva, Nadezhda. 2011. Актантная деривация и лабильность глагола в кла-дан [argument structure derivation and lability in Kla-Dan]. Acta Linguistica Petropolitana VII(2). 218-262.

Makeeva, Nadezhda. 2013. Коммуникативные стратегии и коррелятивная конструкция в языке кла-дан и других южных манде [Information structure and correlative construction in KlaDan and other Southern Mande]. Voprosy Jazykoznanija 1. 77-94.

Michael, Lev, 2014. The Nanti reality status system: Implications for the typological validity of the realis/irrealis contrast. Linguistic Typology 18 (2), 251-288.

Miestamo, Matti. 2005. Standard negation: The negation of declarative verbal main clauses in a typological perspective (Empirical approaches to language typology 31). Berlin: Mouton de Gruyter.

Nichols, Johanna. 1988. On alienable and inalienable possession. In William Shipley (ed.), In honor of Mary Haas, 555-609. Berlin: De Gruyter Mouton.

Nichols, Johanna, 1992. Linguistic diversity in space and time. University of Chicago Press, Chicago.

Nikitina, Tatiana. 2008. The mixing of syntactic properties and language change. PhD dissertation: Stanford University.

Nikitina, Tatiana, 2009. The syntax of PPs in Wan, an "SOVX" language. Studies in Language 33 (4), 907-930.

Nikitina, Tatiana, 2011. Categorical reanalysis and the origin of S-O-V-X word order in Mande. Journal of African Languages and Linguistics 32 (2), 251-273.

Nikitina, Tatiana, 2012. Clause-internal correlatives in Southeastern Mande: A case for the propagation of typological rara. Lingua 122, 319-334.

Nikitina, Tatiana, 2018a. When linguists and speakers do not agree: The endangered grammar of verbal art in West Africa. Journal of Linguistic Anthropology 28 (2), 197-220.

Nikitina, Tatiana, 2018b. Verb phrase external arguments in Mande. New evidence for obligatory extraposition. Natural Language \& Linguistic Theory 37, 693-734.

Paperno, Denis, 2014. Grammatical sketch of Beng. Mandenkan 51, 1-130.

Perekhvalskaya, Elena. 2017. Муан язык [the Mwan language]. In Valentin Vydrin, Yulia Mazurova, Andrej Kibrik \& Elena Markus (eds.), Jazyki mira: Jazyki mande (Языки мира: Языки манде) [Languages of the world: Mande languages], 718-765. St. Petersburg: Nestor-Historia.

Robert, Stéphane. 2010. Clause chaining and conjugations in Wolof. A typology of parataxis and its semantics. In Isabelle Bril (ed.), Clause linking and clause hierarchy: Syntax and pragmatics, 469-498. Amsterdam: John Benjamins.

Singer, Ruth.2001. The inclusory construction in Australian languages. Honours Dissertation: University of Melbourne. 
Singh, Rajendra. 2005. Reduplication in Modern Hindi and the theory of reduplication. In Bernard Hurch (ed.), Studies in Reduplication (Empirical approaches to language typology 28), 261-282. Berlin: Mouton de Gruyter.

Smith-Stark, Timothy Cedric. 1974. The Plurality Split. In Michael W. La Galy, Robert Allen Fox \& Anthony Bruck (eds.), Papers from the tenth regional meeting of the Chicago Linguistic Society, 657-671. Chicago: Chicago Linguistic Society.

Sofu, Hatice. 2005. Acquisition of reduplication in Turkish. In Bernard Hurch (ed.), Studies in reduplication (Empirical approaches to language typology 28), 493-510. Berlin: Mouton de Gruyter.

Terrill, Angela. 2003. A grammar of Lavukaleve. Berlin: De Gruyter Mouton.

Tesnière, Lucien. 1951. Le duel sylleptique en français et en slave. Bulletin de la Société de Linguistique de Paris 47. 57-63.

Thompson, Sandra A., Robert E. Longacre \& Shin Ja J. Hwang. 1997. Adverbial clauses. In Timothy Shopen (ed.), Language typology and syntactic description. vol. 2: Complex constructions, 237-300. Cambridge: Cambridge University Press.

UBS (ed.). 1978. New Testament in Mano. Translation by June M. Hobley Jackson and Stanley Younguoi. Monrovia: United Bible Societies in Liberia.

van der Wal, Jenneke, Larry M. Hyman (eds.), 2016. The conjoint/disjoint alternation in Bantu (Trends in linguistics. Studies and monographs 301). Berlin: De Gruyter Mouton.

van Lier, Eva, Marlou van Rijn. 2013. Argument coding in nominalizations of Central-Eastern Oceanic languages. Lingue e Linguaggio 12 (2), 279-306.

Van Valin, Robert D. 2005. Exploring the Syntax-semantics interface. Cambridge: Cambridge University Press.

Verstraete, Jean-Christophe. 2005. The semantics and pragmatics of composite mood marking: The non-Pama-Nyungan languages of northern Australia. Linguistic Typology 9 (2), 223-268.

Veselinova, Ljuba N. 2006. Suppletion in verb paradigms (Typological studies in language 67). Amsterdam: John Benjamins.

Vydrin, Valentin. 2006. К реконструкции фонологического типа и именной морфологии праманде [Towards the reconstruction of the phonological type and nominal morphology of Proto-Mande]. Acta Linguistica Petropolitana II (2), 9-252.

Vydrin, Valentin. 2008. Стратегии релятивизации в языках манде (на примере дан-гуэта и бамана) [Relativization strategies in Mande (a case study of Dan-Gweetaa and Bamana)]. Африканский сборник-2007 [African collection-2007]. Nauka, Saint-Petersburg, pp. 320-330.

Vydrin, Valentin. 2011. Ergative/Absolutive and Active/Stative alignment in West Africa: The case of Southwestern Mande. Studies in Language 35 (2), 409-443.

Vydrin, Valentin. 2016. Toward a Proto-Mande reconstruction and an etymological dictionary. In Konstantin Pozdniakov (Ed.) Faits de Langues (Comparatisme et Reconstruction: Tendances Actuelles) vol. 47. 109-123.

Vydrin, Valentin. 2017. Дан язык [The Dan language]. In Valentin Vydrin, Julia Mazurova, Andrey Kibrik \& Elena Markus (eds.), Языки мира. Языки манде [Languages of the world. Mande languages], 469-582. Saint Petersburg: Nestor-Istorija.

Vydrin, Valentin. 2018. Mande Languages. Oxford research encyclopedia of Linguistics. Oxford: Oxford University Press. https://oxfordre.com/linguistics/view/10.1093/acrefore/ 9780199384655.001.0001/acrefore-9780199384655-e-397?rskey=JnwnlZ\&result=1. 
Vydrin, Valentin \& Mongnan Alphonse Kessegbeu. 2008. Dictionnaire Dan-Français (dan de l'Est) avec une esquisse de grammaire du dan de l'Est et un index français-dan. Saint Petersburg: Nestor-Istorija.

Vydrin, Valentin, Julia Mazurova, Andrey Kibrik \& Elena Markus (eds.). 2017. Языки мира. Языки манде [Languages of the world. Mande languages]. Saint Petersburg: Nestor-Istorija.

Vydrina, Alexandra. 2011. Лабильность в языке какабе [Lability in the Kakabe language]. Acta Linguistica Petropolitana VII(2). 174-217.

Vydrine, Valentin. 2004. La réduplication des adjectifs dans les langues mandé. Mandenkan 39. $61-67$.

Vydrine, Valentin, Ted G. Bergman \& Benjamin Matthew. 2000. Mandé language family of West Africa: Location and genetic classification. SIL Electronic Survey Reports 2000-003. https:// www.sil.org/silesr/2000/2000-003/silesr2000-003.htm.

Vafaeian, Ghazaleh, 2013. Typology of nominal and adjectival suppletion. STUF - Language Typology and Universals 66 (2), 112-140.

Welmers, William E. 1973. African language structures. Berkeley: University of California Press.

Winkler, Elizabeth Grace, Samuel Gyasi Obeng. 2003. A comparison of reduplication in Limonese Creole and Akan. In Kouwenberg, Sylvia (ed.), Twice As meaningful: Reduplication in pidgins, creoles and other contact languages, 111-119. London: Battlebridge Publications.

Yap, Foong Ha, Karen Grunow-Hårsta \& Yanick Wrona (eds.). 2011. Nominalization in Asian languages. Diachronic and typological perspectives (Typological studies in language 96). Amsterdam: John Benjamins. 